This manuscript is a preprint formally accepted for publication in Basin Research. The final version of this manuscript will be available via the 'Peer-reviewed Publication DOI' link on the right-hand side of this webpage. Please feel free to contact any of the authors directly if you wish to discuss any aspect of the work. 


\title{
Leaky salt: pipe trails record the history of cross-evaporite fluid escape in the northern Levant Basin, Eastern Mediterranean
}

Davide Oppo $^{a *}$, Sian Evans ${ }^{b}$, David Iacopinic, SM Mainul Kabir ${ }^{d}$, Vittorio Masellie, Christopher A-L. Jackson ${ }^{b}$

a Sedimentary Basins Research Group, School of Geosciences, University of Louisiana at Lafayette, Lafayette, USA

${ }^{\mathrm{b}}$ Basins Research Group (BRG), Department of Earth Science \& Engineering, Imperial College, London, UK

${ }^{c}$ Dipartimento di Scienze della Terra, dell'Ambiente e delle Risorse (DiSTAR), Universita di Napoli Federico II, Napoli, Italy

d School of Geosciences, University of Aberdeen, Aberdeen, UK

e Department of Earth and Environmental Sciences, Life Sciences Centre, Dalhousie University, Halifax, Nova Scotia, Canada

*Corresponding author: davide.oppo@louisiana.edu

\section{Keywords}

Fluid escape; Overpressure; Fluid pipe; Cross-evaporite escape; Salt leakage; Focused fluid flow; Eastern Mediterranean

\begin{abstract}
Despite salt being regarded as an extremely efficient, low-permeability hydraulic seal, an increasing number of cross-evaporite fluid escape features have been documented in salt-bearing sedimentary basins. Because of this, it is clear that our understanding of how thick salt deposits impact fluid flow in sedimentary basins is incomplete. We here examine the causes and evolution of cross-evaporite fluid escape in the northern Levant Basin, Eastern Mediterranean. High-quality 3D seismic data offshore Lebanon image hundreds of supra-salt fluid escape pipes distributed widely along the margin. The pipes consistently originate at the crest of prominent sub-salt anticlines, where overlying salt is relatively thin. The fact the pipes crosscut the salt suggests that hydrofracturing occurred, permitting focused fluid flow. Sequential pipes from unique emission points are organized along trails that are several kilometers long, and which are progressively deformed due to basinward gravity gliding of salt and its overburden. Correlation of pipes in 12 trails suggests margin-wide fluid escape started in the Late Pliocene/Early Pleistocene, coincident with a major phase of uplift of the Levant margin. We interpret that the consequent transfer of overpressure from the central basin area, in addition to gas exsolution from hydrocarbons already trapped in sub-salt anticlines, triggered seal failure and cross-evaporite fluid flow.
\end{abstract}


We infer that other causes of fluid escape in the Eastern Mediterranean, such as subsurface pressure changes driven by sea-level variations and salt deposition associated with the Messinian Salinity Crisis, played only a minor role in triggering cross-evaporite fluid flow in the northern Levant Basin. Further phases of fluid escape are unique to each anticline and cannot be easily correlated across the margin. Therefore, despite a common initial cause, long-term fluid escape proceeded according to structurespecific characteristics, such as local dynamics of fluid migration and anticline geometry. Our work shows that the mechanisms triggering cross-evaporite fluid flow in salt basins vary in time and space.

\section{Introduction}

The important role of salt in controlling fluid migration and accumulation has been described in various basins worldwide. In particular, salt acts as seals for hydrocarbon reservoirs and $\mathrm{CO}_{2}$ and nuclear waste storage sites (Berlepsch and Haverkamp, 2016; Selley and Sonnenberg, 2015; Warren, 2016). Salt commonly forms excellent membrane and hydraulic seals because of its extremely low permeability (Warren, 2017, 2016), potentially allowing volumetrically significant, sub-salt fluid and gas accumulations (e.g. Esestime et al., 2016). However, recent research shows that salt is not a perfect seal (Warren, 2017, 2016). Tectonic evolution (e.g. basin uplift, thick-skinned faulting, halokinesis), excessive overpressure, and interaction with pore fluids can reduce or completely destroy the sealing capacity of salt (Davison, 2009; Schoenherr et al., 2007; Warren, 2017). This disruption can potentially prevent the accumulation and preservation of hydrocarbons within pre-salt units, drastically change the fluids migration pathways, and cause contamination of aquifers by nuclear waste (e.g. Davison, 2009; Jackson and Hudec, 2017; Schoenherr et al., 2007; Warren, 2017).

Cross-evaporite fluid escape has been mainly studied in mature salt basins where extensive salt tectonics has occurred and large structures, like diapirs, are present (Andresen et al., 2011; de Mahiques et al., 2017; Salazar et al., 2014). However, a lack of high-quality outcrop of subsurface datasets of sufficient extent to reveal the true three-dimensional relationship between large salt structures, their overburden, and related fluid flow features, limits our knowledge of cross-evaporite processes and products in even relatively undeformed salt basins. Seismic data has also only relatively recently been able to resolve and thus permit detailed mapping of relatively small fluid escapes features (e.g. fluid escape pipes $<200 \mathrm{~m}$ in diameter; e.g. Evans et al., 2020; Kirkham et al., 2019). For these reasons, the processes and products of cross-evaporite fluid escape remain poorly understood in the history of a salt basin not yet influenced by 
mature halokinesis (i.e. where extensive vertical salt movement did not occur). To fully understand the limits of salt as sealing unit, it is fundamental to evaluate the mechanisms governing cross-evaporite fluid escape and to reconstruct the fluid escape history. We can thus obtain the necessary information to reconstruct fluid generation and migration in rapidly deforming natural geological systems, such as those typified by salt basins.

The numerous fluid escape features, a kilometers-thick relatively undeformed salt sheet, and the known basin deformation history make the Eastern Mediterranean the perfect case study to investigate crossevaporite fluid escape, from which we can develop models that can be applied worldwide. Widespread fluid escape in the Eastern Mediterranean started during the Messinian and continues today (e.g. Bertoni et al., 2017; Dimitrov and Woodside, 2003; Eruteya et al., 2015; Loncke et al., 2004; Zitter et al., 2005). During the Messinian Salinity Crisis (MSC) the isolation of the Mediterranean Sea from the Atlantic Ocean led to the relatively rapid deposition of a thick, halite-dominated evaporite sequence (Haq et al., 2020; Roveri et al., 2014 and references therein). The Messinian salt reaches a thickness of c. 2 km over most of the deep water Eastern Mediterranean (Haq et al., 2020; Lofi et al., 2011). Because of the Messinian salt, which acts as seal rock, various giant hydrocarbon fields occur in the underlying, sub-salt sequences (Esestime et al., 2016; Gardosh and Tannenbaum, 2014; Ghalayini et al., 2018). However, the seal is not perfect (e.g. Bertoni et al., 2017). Despite most fluid escape features, both within the subsurface and at the surface, appear to originate within supra-salt sedimentary sequences (Bertoni et al., 2017), numerous cross-evaporitic features are observed, thus pointing to a long fluid escape history started in the Messinian and continued until recently (Bertoni et al., 2017; Gradmann et al., 2005; Kirkham et al., 2017; Netzeband et al., 2006).

Fluid escape systems can be regionally active on a multi-million-year time scale (Capozzi et al., 2017; Maestrelli et al., 2017). However, reconstructing the timing and evolution of repeated fluid expulsion events can be challenging because their expression in seismic reflection data may overlap in time and space, and thus they may not be represented by discrete features. In the northern Levant Basin, part of the Eastern Mediterranean, distinct fluid expulsion events from common leakage points formed crossevaporite fluid escape pipes (Cartwright et al., 2018; Kirkham et al., 2019). These fluid escape pipes are clearly preserved in the stratigraphic record due to the coeval and still-active Messinian salt tectonics. Salt-detached gravity gliding of the overburden progressively translates the pipe away from the original emission point and towards the deeper basin (Cartwright et al., 2018). The basinward displacement of the overburden crosscut by the pipes allows the translation of an unaltered sediment pile above the emission 
point, which is able to record new fluid escape events. This process deforms the intra-salt portion of fluid escape pipes from an initially vertical to an arcuate geometry (Cartwright et al., 2018). This means that successive fluid escape events from various unique leakage points form trails of deformed pipes and overlying pockmarks. This fluid escape process has been only recently described for the first time (Cartwright et al., 2018; Kirkham et al., 2019). The authors studied five pipe trails to infer the kinematics of the Messinian salt layer in this region. However, the causes, significance, and implications of the pipe trails have never been analyzed in detail at the basin scale. To date, no similar examples are documented in other sedimentary basins worldwide.

The exceptional pipe trails in the northern Levant Basin hold important, spatial and temporal highresolution information on the processes regulating fluid escape establishment, duration, and cyclicity in the period following the deposition of a thick evaporite unit along a continental margin. We use highquality 3D seismic reflection data from offshore Lebanon (Fig. 1) to illustrate the causes and history of cross-evaporite fluid escape in this region of the Eastern Mediterranean. We analyze the distribution and spacing of the fluid escape pipes within twelve trails to reconstruct the history of fluid migration, charge, and expulsion. In doing so, we demonstrate that basin-scale tectonic events, rather than events explicitly associated with the MSC itself, are responsible for cross-evaporite fluid escape in this area of a relatively undeformed salt giant.

\section{Geological setting}

The Levant Basin mainly formed during multiphase rifting linked to opening of the Neotethys Ocean during the Permo-Triassic and Jurassic (Nader et al., 2018). Since the Late Cretaceous, this region has been shaped by the collision of the African and Eurasian plates, with the former being subducted beneath the latter. Plate collision led to the formation of the Latakia Ridge as part of the Cyprus Arc System (Robertson et al., 1996). The northern Levant Basin, the focus of this study, formed during the Oligocene within the overall compressive regime (Steinberg et al., 2011). Compression led to folding and thrusting along the basin eastern margin, leading to the generation of NE-trending anticlines that deformed the OligoMiocene sedimentary units prior to, or at the onset of, the Messinian Salinity Crisis (MSC) (Ghalayini et al., 2014; Hawie et al., 2013). The lack of visible deformation of the post-Messinian overburden, possibly because of the accommodation of anticline amplification within the salt, makes it difficult to confidently demonstrate post-Messinian growth of the sub-salt anticlines (Ghalayini et al., 2014). The Saida-Tyr 
platform represents the boundary between the northern and southern Levant Basin, and forms the southern limit of the study area. The northern boundary of the Saida-Tyr platform is represented by the Saida fault, an Early Mesozoic normal fault that was reactivated under dextral transpression during the Late Miocene (Ghalayini et al., 2018, 2014). This reactivation deformed the Tertiary sedimentary units, generating several anticlines bordering the northwestern flank of the Saida-Tyr platform. Tectonic activity in the northern area of the basin during the Late Miocene-Pliocene also reactivated the Latakia Ridge under sinistral transpression (Hall et al., 2005), promoting the growth of thrust-related folds on its southeastern side. A fundamental tectonic event started at the end of the Messinian when activity on the Levant Fracture System, onshore Lebanon and Israel gradually uplifted the eastern margin of Levant Basin (Gvirtzman et al., 2013). The rate of uplift was not constant, with higher rates occurring during the Late Miocene-Pliocene (Ghalayini et al., 2018) and Late Pleistocene (Matmon et al., 1999). Uplift and associated tilting of the eastern basin margin, as well as differential loading, led to gravity-driven salt tectonics that resulted in flow of the Messinian salt towards the deep basin (Allen et al., 2016; Cartwright and Jackson, 2008; Gvirtzman et al., 2013). Salt movement resulted in three kinematically-linked domains that trend broadly parallel to the basin margin: 1) an updip extensional domain, characterized by marginparallel growth faults; 2) a central translational domain, characterized by limited deformation of the overburden, but intense intra-salt deformation; 3) a downdip contractional domain, containing widespread thrusting and folding of both the salt and overburden (Allen et al., 2016; Cartwright and Jackson, 2008).

The lack of well data in the northern Levant Basin prevents the exact calibration of the basin-fill stratigraphy; age constraints are instead inferred by correlation with units preserved onshore Lebanon and the southern Levant Basin (Gvirtzman et al., 2013; Hawie et al., 2013; Meilijson et al., 2019). Mesozoic deposits, formed by deep-water carbonates and siliciclastics, are thought to be overlaid by a $>7 \mathrm{~km}$-thick Cenozoic succession (Ghalayini et al., 2018). Undercompacted Paleogene shales pass upwards into OligoMiocene siliciclastic sediment, sourced from the proto-Nile delta and by the erosion of the uplifting Levant basin margins (Ghalayini et al., 2018). During the MSC, an up to c. $2 \mathrm{~km}$-thick evaporite-dominated succession was deposited in most of the Levant Basin. Following this, a brief phase of evaporite fluvial reworking deposited the Nahr Menashe Unit in the northern Levant Basin (Kabir et al., 2019), which subsequently experienced fluvial incision and deposition (Madof et al., 2019). Marine flooding of the basin at the end of MSC and the renewed siliciclastic influx deposited a Plio-Pleistocene succession that, within the study area, is thought to be composed of hemipelagic and pelagic sediment (Hawie et al., 2013). 
The petroleum system offshore Lebanon is still under-explored and thus poorly understood. However, direct hydrocarbon indicators and stratigraphic correlation with nearby areas point to a potentially prolific basin. Many possible source rocks spanning from the Permian/Triassic to the Miocene are identified in various areas of the basin (Barabasch et al., 2018; Ghalayini et al., 2018; Marlow et al., 2011). Thermogenic hydrocarbon generation has been active since the Late Cretaceous in the deeper basin and Latakia Ridge (Bou Daher et al., 2016), whereas biogenic methane generation started in the Miocene across the Lebanese offshore. Biogenic methane generation still occurs in the upper part of the sub-salt Miocene sediments along the basin margins and in the shallower units on the Latakia Ridge (Ghalayini et al., 2018). The reservoir units are composed of Oligo-Miocene deep-water sandstones deformed in Syrian Arcrelated structural traps. The most notable traps are NE-trending, Oligo-Miocene anticlines and Early Miocene fault blocks (Ghalayini et al., 2018). The main seals in the Levant Basin comprise fine-grained sediments interbedded within the Oligo-Miocene reservoirs and, ultimately, the thick Messinian salt (Ghalayini et al., 2018).

\section{Material and Methods}

The seismic data used for this study are a post-stack time migrated 3D multi-channel seismic reflection survey (MC3D LEB MegaSurvey Plus) acquired by PGS between 2006 and 2013. The seismic survey covers $\sim 10,000 \mathrm{~km}^{2}$ offshore Lebanon in water depths between 200 and $1900 \mathrm{~m}$ (Fig. 1). The data are near-zero phase at the seafloor reflection and are displayed here with SEG negative polarity; i.e. a downward increase in acoustic impedance is represented by a trough (red color) and termed a "hard kick", whereas a peak (black color) represents a downward decrease in acoustic impedance and is termed a "soft kick" (Brown, 2001). The seismic data are presented in Two-Way Travel Time (TWTT).

The dominant frequencies of the seismic data are $50 \mathrm{~Hz}$ in the post-salt overburden, $25 \mathrm{~Hz}$ in the Messinian salt, and $17 \mathrm{~Hz}$ in the sub-salt units. Average P-wave velocities for these intervals $(2,000 \mathrm{~m} / \mathrm{s}, 4,200 \mathrm{~m} / \mathrm{s}$ and 3,000 m/s, respectively) are derived using information from six exploration wells in the southern Levant Basin (Feng et al., 2016) and proprietary data processing reports provided by PGS Geophysical AS. Based on these data, the estimated vertical resolution (i.e. tuning thickness) of the post-salt, Messinian salt, and sub-salt units, calculated as a quarter of the dominant wavelength, are 10, 42 and $44 \mathrm{~m}$ (average), respectively. Horizontal resolution for the 3D binned, migrated (Kirchhoff) and processed data can be approximated as a quarter of the dominant wavelength down to the minimum limit dictated by the bin 
spacing (Lebedeva-Ivanova et al., 2018; Widess, 1973; Yilmaz, 2001). Bin dimensions were 25 x 25 m during data processing. Hence, the best horizontal resolution we can achieve is c. $25 \mathrm{~m}$ within the entire imaged sedimentary succession. However, our ability to recognize geological features, defined as detectability or limit of visibility (Brown, 2011; Yilmaz, 2001), is different from both the vertical and the horizontal resolutions and extends beyond them (Reijenstein et al., 2011; Zhang and Castagna, 2011). Therefore, we can describe geological features or patterns smaller than the tuning thickness and bin size down to c. $1 / 8$ of the dominant frequency (Kallweit and Wood, 1982; Widess, 1973; Zhang and Castagna, 2011), although we are limited in the capacity to quantify volumes (Brown, 2011).

We used the seismic data to map the top-salt (TS) and base-salt (BS), and key horizons in the overburden (e.g. the 1.8 Ma reflection derived from Kirkham et al. (2019), see Section 5). Post-stack seismic attributes, including Variance (Chopra and Marfurt, 2007) and Root Mean Square (RMS) amplitude, were calculated (Barnes, 2016). Variance was used to highlight fluid escape features and structural discontinuities (i.e. faults). RMS amplitude was calculated to image anomalous amplitudes inferred to be driven by variations in pore fluid and/or gas (herein termed 'fluid' to include pore water, gas, and liquid hydrocarbon), and/or variations in the degree of sediment lithification. Amplitude anomalies are qualitatively defined as zones where the amplitude of reflections is distinctly higher than the average value of nearby areas, whereas Vertical Anomaly Clusters (VAC) are defined as a vertical region of amplitude anomalies inferred to be genetically linked by fluid migration processes (Foschi et al., 2014). Interpreting features close to data resolution within successions rich in fluids can pose significant challenges as the presence of fluids and/or the similarity between the features diameter and the seismic data resolution may generate seismic imaging artifacts (pull-up and/or push-down) (Brown, 2011). Pull-up features (i.e. anticlines) can be also created in the sub-salt by the higher velocity of seismic waves through salt intervals. Despite the presence of a thick salt layer, the salt thinning above the Miocene sub-salt anticlines within this dataset indicates that they are real geological structures. Additionally, they are also clearly imaged in the work of Ghalayini et al. (2014), who presents this seismic dataset converted in depth. Unfortunately, we were not able to do the same because the lack of a velocity model.

\section{Results}

4.1. Seismic expression of fluid escape features 
In the northern Levant Basin, we classified 325 vertical seismic data anomalies as fluid escape pipes according to well-established recognition criteria (Cartwright and Santamarina, 2015; Moss and Cartwright, 2010). The fluid escape pipes (herein termed 'pipes') are narrow vertical areas of locally disrupted and/or attenuated seismic reflections (Fig. 2). These areas are roughly circular in planform, varying from near-seismic resolution (c. $25 \mathrm{~m}$ ) to c. $255 \mathrm{~m}$ in diameter. Pipes taper either upwards or downwards, or maintain their diameter over their visible depth range (Fig. 2). The pipe root zone is frequently difficult to image because of the seismic signal degradation beneath the thick evaporite units, as well as the depth at which the root zone lies. Nevertheless, we recognized that all pipes originate at the base-salt or within the sub-salt units, and no examples are present solely within the post-salt overburden.

The upper terminus of the pipes is either a pockmark or a small mud volcano, indicating the present or past expulsion of fluid and sediment at the seafloor or paleo-seafloor (Fig. 2). The narrower pipes seldom show recognizable internal geometries and appear as zones of dimmed seismic signal (Fig. 2a,b). In contrast, the larger pipes (diameter $>100 \mathrm{~m}$ ) have internal characteristics that commonly relate to the type of upper terminus. More specifically, when either a paleo- or present-day pockmark occurs, the reflections internal to the pipes are either concave-downward, or disrupted and chaotic (Fig. 2c). When the upper terminus is a mud volcano, and the pipe is thus inferred to be associated with significant sediment remobilization, the pipe internal reflections have convex-upward geometries, which may become chaotic and concave upwards (Fig. 2d).

The pipes are either linear or arcuate in section. Linear pipes connect vertically aligned root and terminus, and terminate at or near the present-day seafloor (e.g. Fig. 3). Arcuate pipes are gently dipping at their roots near base-salt, increasing in dip upwards to top-salt and becoming vertical in their extension within the overburden (Fig. 3). These two geometries also have a different seismic response within the evaporite unit. Whereas all the vertical and most of the arcuate pipes are in agreement with the general model (i.e. disrupted and attenuated signal), the deformed portion of the pipes are often characterized by a narrow, linear, high-amplitude reflection with a soft-kick response (see also Kirkham et al., 2019). Often, the pipe root is shifted downwards along the flank of an anticline underlying the salt (e.g. Fig. 3). Based on the pipes geometrical and amplitude characteristics, an alternative origin as intrasalt deformation can be excluded. Deformed intrasalt layers related to shortening would occur as salt sheet-normal zones and not as straight trail-like zones parallel to the direction of deformation. Additionally, we are not aware of any salt deformation that is consistently overlain by a pipe (or pipes) in the overburden. The fact that the intra- 
and suprasalt features we observe are always overlain argues strongly for a genetic relationship between the two.

The pipes in Fig. 3 show the variation in terminus style moving landwards. The terminus of the first pipe has a mounded morphology defined by a hard kick with an amplitude anomaly on top (Fig. 3b). This mound is onlapped by reflections of which the first overlying $68 \mathrm{~ms}$ TWT are deflected upwards (Fig. 3a). The base of the mounded feature is a soft kick that lies on the onlap surface of a ramp syncline basin (RSB; see Section 4.2 for details). These characteristics indicate that the mounded feature is real and not a seismic artifact, and that it likely formed positive relief on the paleo-seafloor. The basal reflection of the mounded feature is concave downward at the top of the underlying pipe. The internal geometries of the mounded feature are difficult to determine because of the seismic resolution, but they appear to be discordant with the overlying, relatively flat-lying, onlapping reflections. Comparable geometries and reflection polarities have been documented in buried mud volcanoes (e.g. Hansen et al., 2005). Moving further landwards still, the pipe terminus appears to transition from mud volcano to buried pockmark (Fig. 3d), a relationship clearly imaged in Fig. 3e. The last pipe forms a pockmark on the present-day seafloor, recording relatively recent seepage of fluids (Fig. 3f).

\subsection{Basin-scale distribution and salt-tectonic context of fluid escape features}

In the northern Levant Basin, fluid escape mainly occurs along the eastern margin of the salt translational domain, where most of the pipes fall into one of 12 trails (Pipe Trails, PT1-12; Fig. 4). We define a trail as a series of roughly aligned pipes that lie within a $250 \mathrm{~m}$-wide area defined around the central trail trend (see inset in Fig. 4). The pipe trails trend approximately NW, broadly parallel to regionally extensive subsalt faults (Fig. 4). These Miocene normal faults seldom extend upwards into the salt (Ghalayini et al., 2018). Despite similar trends, we do not observe a direct connection between the pipe roots and the faults. This observation is supported by trails PT2 and PT3, which have an overall different trend respect to the faults (Fig. 4). The trails are c. 2.3 to $12 \mathrm{~km}$ long when measured from the inferred fluid leakage area, which is consistently associated with one of the NE-trending, sub-salt anticlines. Various NE-trending anticlines are documented in the Lebanese offshore, but fluid escape occurs only when fluid accumulation combines with significant salt thinning (c. $250-500 \mathrm{~m}$ ) above the anticlines (Fig. 5). The overall thickness of the Messinian salt varies from over $1 \mathrm{~km}$ in the central basin to zero at the eastern basin margin and at 
the Latakia Ridge (Fig. 5). One additional small trail occurs within the salt contractional domain of the basin outside the seismic data analyzed in this study (Fig. 4, Oceanus structure) (Cartwright et al., 2018).

All pipe trails are associated with Ramp Syncline Basins (RSBs) (Evans et al., 2020) (Fig. 6). RSBs form in response to the down-dip translation of the overburden across a detachment ramp, with the concomitant creation of accommodation at sediment onlap onto the RSB hinge (Jackson and Hudec, 2005; Pichel et al., 2018). Continuous translation leads to the downward rotation of the older syn-kinematic onlaps, which transform into pseudo-downlaps and define pseudo-clinoforms (Jackson and Hudec, 2005; Pichel et al., 2018). Consequently, the diachronous surface formed by the onlaps represents a continuum of paleodepocenters and records the history of salt and overburden movement (Evans and Jackson, 2019). After vertical pipes are formed above the sub-salt anticlines, they are translated into the RSB depocenter and progressively buried. The pipes therefore terminate upwards at an onlap surface defining the base of the coeval RSBs (Fig. 6). This means that the age of each pipe in the trail can be approximated by the age of the corresponding intra-RSB stratigraphic surface. In each pipe trail, the pipe culminations (i.e. pockmarks or mud volcano) occur within progressively younger sediments updip toward their source anticlines. The pipe positioned furthest basinward represents the first (i.e. the oldest) cross-evaporite fluid migration event of the trail, whereas the pipe closest to the anticline, occasionally forming a present-day pockmark (Fig. 6b), is the youngest (Cartwright et al., 2018; Kirkham et al., 2019).

Not all pipes are organized in trails. An exceptional cluster of pipes occurs SE of the Latakia Ridge. Here, c. 50 pipes propagate from the culmination of a sub-salt thrust anticline where the evaporite cover is absent and a primary weld (sensu Wagner and Jackson, 2011) occurs (Fig. 7). In the surrounding region, where salt occurs, there is no cross-evaporitic fluid escape (Figs. 7, 8). The pipes crosscut the PlioQuaternary overburden, occasionally reaching the seafloor and forming several pockmarks. The pockmarks are confined within a $2.5 \times 4.7 \mathrm{~km}$, up to $60 \mathrm{~m}$ deep depressed area directly overlying the fluid escape zone. A mounded feature occurs in the depressed area and shows a central elongated depression on its southern side (Fig. 8a).

\subsection{Amplitude anomalies and lateral fluid diffusion}

The fluid pipes are frequently associated with single or multiple reflections showing increased amplitude with respect to the host unit (herein termed amplitude anomalies). The amplitude anomalies are commonly within, and in proximity of, the pipes (Fig. 3), or at their upper terminus (Fig. 2c). Amplitude 
anomalies only occur in the post-salt sedimentary succession. The anomalies may extend laterally, concordant with the host stratification, from the pipes up to c. $1 \mathrm{~km}$ and either have sharp amplitude cutoffs at their edges or progressively reduce in amplitude. At the edge of the amplitude anomalies, the lack of evident discontinuities or likely lithology change indicate a change in the seismic response of the sedimentary strata (Fig. 3). Occasionally, amplitude anomalies originate from minor normal faults overlying the interval affected by the pipes (e.g. Fig. 6).

We classify subvertical groups of amplitude anomalies as vertical anomaly clusters (VAC) following the definition by Foschi et al. (2014). VACs are observed offshore Lebanon within anticlines associated with RSBs (Fig. 3), around the pipe cluster at Latakia Ridge (Fig. 7, 8), and within contourite-like deposits (Fig. 9). A VAC develops from the post-salt portion of a mud volcano feeder pipe and extends up-dip towards the culmination of a small contourite-like deposit (Fig. 9). An RMS amplitude map shows a direct connection between the mud volcano feeder pipe and the VAC, thus evidencing a possible genetic relation between the anomalies and the cross-evaporite fluid escape features, which can promote extensive lateral fluid migration, and possible accumulation, through carrier beds in the post-salt overburden.

The Latakia Ridge pipe cluster is associated with the largest VAC in the dataset (Fig. 8). A complex VAC extends laterally from the pipes along the anticline axis for a total length of c. $10 \mathrm{~km}$. The anomaly cluster has a maximum thickness of c. $200 \mathrm{~ms}$ in the northeastern half, and tapers to only two reflections on its SW side. Whereas the NE portion of the VAC is well-defined, the SW sector is dissected by numerous normal faults that offset the anomalies. A basal anomaly delimits the lower edge of the VAC, whereas its upper limit is more fragmented (Fig. 8d). A flat soft kick anomaly delineates the upper VAC in the pipes area and transitions laterally to reflections apparently dipping NE; this anomaly has a very limited lateral extension in the NW-SE direction and its origin remains unclear. The flatness rapidly disappears moving laterally (Fig. 7), with this feature not thought to be a bottom simulating reflection (BSR) given its geometry is independent from that of seafloor. The possibility of it being a hydrocarbon-generated flat spot is excluded because its soft kick character.

\subsection{Distribution of pipes within trails}

For every trail we measured the distance of each pipe from its leakage point (Fig. 10) and plotted it against time intervals (T1 to T11), derived by our regional correlation of intra-RSB units (see also Evans et al. 2020). Because the lack of subsurface data in the basin, these time intervals are relative. Therefore, they are not 
associated with an absolute age marker other than 1.8 Ma (from Kirkham et al., 2019) and $0 \mathrm{Ma}$ (the seafloor). We observed that the pipes have a first-order distribution, in which a small but well-defined cluster of closely spaced $(<1 \mathrm{~km}$ ) pipes, or a single pipe, is separated from younger features by a c. $1 \mathrm{~km}$ gap. These younger pipes are more widely dispersed along the trail length, occasionally forming individual clusters separated by smaller gaps.

In addition to this distribution, which correlates the inferred trend of fluid emission among anticlines at the basin scale, a more unique, somewhat second-order distribution of pipe spacing and formation is observed within each trail. For example, PT2 shows long quiescence intervals between periods of intense pipe formation. Similar higher and lower frequency alternations of fluid escape and quiescence periods occur in all trails. PT6 shows a clear decrease of pipe frequency towards more recent times; this trend is also observed in PTs 4, 5, and 9. An end member is PT 7, which shows only an initial group of pipes and a complete lack of more recent activity.

\section{Discussion}

The 325 mapped fluid escape pipes provide an exceptional record of fluid escape history in the northern Levant Basin. The organization of these pipes into trails records various phases of cross-evaporite fluid escape starting in the Late Pliocene/Early Pleistocene. We analyze trail lengths and pipe distributions to reconstruct the processes that triggered and sustain fluid escape in the basin. The seismic reflection dated 1.8 Ma by Kirkham et al.(2019) in the southern study area provides the only absolute time marker, and we can identify only relative time intervals using this datum as a reference point.

\subsection{Mechanisms of cross-evaporite fluid escape in the northern Levant Basin}

Fluid escape through evaporite seals is difficult because of the intrinsic salt properties, such as its ability to maintain seal integrity, to flow under stress, and to quickly re-anneal fractures (Warren, 2006). However, salt welding, faulting, salt dissolution by undersaturated fluids, and overpressure-related hydrofracturing can promote fluid escape (Warren, 2006). These factors are hypothesized to drive fluid escape in the Eastern Mediterranean because of the unique tectono-stratigraphic development of its constituent sub-basins, generating a wide range of fluid escape features (Bertoni et al., 2017).

In the northern Levant Basin, the start of pipe formation and the main phase of salt movement are nearly simultaneous (Evans et al., 2020), thus suggesting a common trigger mechanism for the two events. 
Despite the temporal coincidence, measured changes in rates of salt movement derived from RSBs do not directly correlate with pipe distribution within the trails (Evans et al., 2020); i.e. increases or decreases of salt gliding rate are not matched by increases or decreases of pipes spacing, respectively. This observation suggests that pipe formation is independent from salt tectonics. Additionally, during the initial stages of gliding the salt was more homogeneously thick thus likely preventing significant variation in the equilibrium of fluids within the underlying sedimentary succession.

Normal faults do not contribute to cross-evaporite fluid escape in the northern Levant Basin. Such structures, which are related to thin-skinned, salt-detached extension, breach the salt seal and create vertical fluid migration pathways in the Cyprus Basin (Hübscher et al., 2009). However, along the northern Levant margin, thin-skinned structures detach within the top of and do not crosscut the evaporite layer. Instead, the fluid pipes are occasionally associated with smaller normal faults that develop within the post-salt sediments and rarely extend down into the salt (Figs. 6a). The location of these faults suggests they formed by a combination of compaction of intra-RSB sediments and overburden folding during saltdetached translation. Amplitude anomalies and VACs in association with the faults show that these latter may favor fluid migration by weakening the overburden and connect intervals with higher permeability, thus promoting both vertical and lateral fluid diffusion within the post-salt sediments. Similar association of amplitude anomalies and faults has been widely documented in areas of fluid migration and escape and is interpreted as an accumulation of either gas-rich fluids, or hydrocarbon-mediated precipitation of authigenic minerals, depending on their soft or hard kick seismic character, respectively (e.g. Gay et al., 2007; Oppo and Hovland, 2019). In this study, given all the amplitude anomalies associated with fluid pipes are soft kicks (e.g. Fig. 3), we infer they reflect higher (gas-rich) fluid saturation. Most likely, the fluids migrating through the pipes are connate water and methane gas, as documented in many examples worldwide (e.g. Cartwright and Santamarina, 2015). The smaller normal faults formed after the deactivation of the pipes and possibly drained any residual fluids from the underlying pipes, thus representing local high-permeability pathways in an otherwise sealing, fine-grained sedimentary succession. We conclude that fault-induced fluid migration within the overburden occurs in the northern Levant Basin as a secondary process, and is not responsible for pipe genesis.

Near the Latakia pipe cluster, E-W-striking normal faults dissect both the pre- and post-salt sedimentary units (Fig 8d). One fault system crosscuts the sub-salt sediments along the entire anticline, possibly favoring vertical fluid migration from deeper units in the area underneath the pipes. Another fault system is mainly confined to the post-salt overburden to the SW of the pipe cluster. Here, the faults displace the 
present seafloor to define several grabens. Although the pipes disrupt the seismic signal and limit the interpretation of the post-salt interval geometries, the faults do not appear to extend into the area where the pipes occur as no seafloor displacement is observed within the depression. Variance and RMS amplitude maps also do not show any evidence for subsurface faults (Fig. 8b-d). The faults in the post-salt irregularly offset the amplitude anomalies originating from the pipe cluster; i.e. the anomalies distribution is incompatible with a progressive vertical fluid migration through the faults. This suggests that the start of fluid escape, or at least the periods of lateral fluid diffusion, predates fault formation. Additionally, the sedimentary sequence and the seafloor in the graben area are barren of features related to vertical fluid migration, which are instead mostly confined within the depressed area. Based on these observations, we suggest that the Latakia supra-salt faults do not have a role in the fluid escape but may act as lateral barriers and/or baffles to fluid movement.

Salt dissolution is suggested to favor cross-evaporite fluid migration in some areas of Eastern Mediterranean, where deep-sourced fluids likely propagated into evaporite units through hydrofracturing and induced salt dissolution and collapse within pipes (e.g. Kirkham et al., 2018). Deep-sourced fluids can dissolve the salt (Cartwright et al., 2001; Fu and Aharon, 1998; McManus and Hanor, 1993) and generate circular depressions on the top-salt as observed in the southern Levan Basin (Bertoni and Cartwright, 2005), or can, in combination with hydrofracturing and sediment withdrawal, cause the entire evaporite and overburden sequence to sag downwards as observed in the mud volcanoes of the Nile deep-sea fan (Kirkham et al., 2018). We do not observe these sag morphologies in association with fluid escape pipes in the northern Levant Basin. It is possible that dissolution also occurred in this area, but the lack of visible evidence points to its negligible role compared to other possible processes, such as overpressure-induced hydrofracturing.

\subsubsection{Overpressure generation and hydrofracturing}

Overpressure and hydrofracturing are the principal causes of cross-evaporite fluid escape in the Eastern Mediterranean (e.g. Bertoni et al., 2017). Salt is excellent seal rock because extremely low permeability, and near-lithostatic overpressure is a critical precondition to reach its fracture threshold (Warren, 2017). The causes for overpressure formation vary (Swarbrick \& Osborne, 1998), and several different mechanisms are proposed within the Eastern Mediterranean. For example, the rapid deposition of thick, pelitic successions in the Nile deep-sea fan led to compactional disequilibrium during burial and to the 
generation of hydrocarbons (Al-Balushi et al., 2016). The resulting supra-lithostatic overpressure led to the development of a large mud volcano province (C Kirkham et al., 2017). The tectonic stress associated with the growth of the Syrian Arc contributed to overpressure generation and drove fluid escape in the Latakia and Cyprus basins, with the formation of intrusive sedimentary bodies and pockmarks (C. Bertoni et al., 2017; Hübscher et al., 2009). Three events associated with the MSC are commonly identified as the main causes of overpressure generation in the Eastern Mediterranean basin: 1) rapid water unloading and pressure release during the initial stages of the MSC, 2) rapid deposition of the thick Messinian evaporite, and 3) water loading during the sea-level rise at the end of the MSC (Claudia Bertoni \& Cartwright, 2015). The juxtaposition of these events during a relatively short period of time during the MSC ( 5.97 to $\sim 5.33$ Ma) (Roveri et al., 2016) profoundly altered the subsurface pressure regime in the Eastern Mediterranean, creating multiple phases of overpressure generation and release.

Across the Eastern Mediterranean, the Nile and southern Levant basins have the longest record of fluid escape, starting in the Late Miocene and continuing until present (Bertoni et al., 2017). Offshore Lebanon, a few pockmarks at the base-salt reflection are the only potential fluid escape features predating the Pliocene (Fig. 6 in Bertoni et al., 2017). Because underlying fluid pipes are not visible in the seismic images, these pockmarks may represent dewatering or gas expulsion from near-seafloor sediments caused by the initial MSC sea level drop. Therefore, the oldest fluid escape pipes in the Lebanese offshore formed during Late Pliocene/Early Pleistocene, thus postdating the end of the MSC by $>2$ Myr. This lag suggests that the MSC did not create sufficient overpressure within the sub-salt traps to reach the near-lithostatic level necessary to fracture the overlying salt. Therefore, fluid escape along the Lebanese margin required other overpressure-inducing mechanisms.

We hypothesize that tilting of the Levant margin was the primary cause for the beginning of extensive fluid escape from sub-salt anticline crests in the northern Levant Basin. The eastern Levant margin has been gradually uplifting since the Late Messinian, which together with differential sediment loading and tectonic subsidence near the Cyprus Arc, triggered salt-detached gravity gliding (Gvirtzman et al., 2013). At the same time, this uplift would have promoted fluid migration from the deep basin towards basin margin anticlines (Fig. 11) (Yardley and Swarbrick, 2000). This mechanism has been described in various sedimentary basins hosting hydrocarbons, such as the Baram and Niger deltas (Leduc et al., 2013; Tingay et al., 2007). In this model, uplift is a key agent for transferring overpressure generated in deeper distal units towards shallower, more proximal successions. Although we cannot conclusively show the past existence of overpressure in the distal Lebanese offshore, it most likely occurred by analogy with the 
southern Levant Basin (Bertoni et al., 2017). Our hypothesis also agrees with models for the regional petroleum system, which postulate up-dip hydrocarbon migration eastwards from biogenic and thermogenic source rocks located towards the deeper basin (Barabasch et al., 2018; Ghalayini et al., 2018; Nader et al., 2018). Besides promoting fluid migration, basin margin uplift may have also reduced the water column along the margin, inducing gas exsolution from the hydrocarbons already trapped in the anticlines, thus increasing overpressure by buoyancy (e.g. Al-Balushi et al., 2016).

In addition to the basin tilt, compressive tectonic stress may have contributed to the buildup of overpressure in sub-salt rocks. The creation and transfer of overpressure by compressive tectonics has been documented in many basins worldwide (Morley et al., 2014), where it can drive fluid escape. The northern Levant Basin has a long history of compressive tectonics (e.g. Hawie et al., 2013). The most recent phases started in the Messinian and formed detachment folds and transpressive strike-slip structures along the eastern margin (Ghalayini et al., 2014). Later, in the Pliocene, the Latakia Ridge shifted from pure compression to transpression (Hall et al., 2005). The fluid escape started shortly after these tectonic phases and originated from structures deformed during this period. We thus suggest a secondary contribution of regional compression to overpressure development.

Therefore, we argue that the main processes responsible for fluid escape genesis in the northern Levant Basin differ from those in the southern Levant and Nile deep-sea fan basins. Whereas events linked to the MSC likely contributed to increasing the pressure within sub-salt reservoir units, the lack of fluid escape features immediately following the MSC indicates that this was (and is) a second-order control. Consequent tectonic activity, at the scale of the northern Levant Basin, had an essential role in creating the near-lithostatic overpressure necessary to generate cross-evaporite fluid expulsion. We argue that the regional tectonics of the margin, more specifically basin tilt, were responsible for promoting both salt movement and fluid leakage.

\subsection{Relationship between fluid escape and salt}

All the documented fluid escape features form at leakage points on the crest of prominent sub-salt anticlines (this study and Cartwright et al., 2018) (Fig. 4). These anticlines act as 4-way-dip closure hydrocarbon traps that allow extensive fluid accumulation, increasing the potential for overpressure generation and hydrofracturing. The pipes predominantly occur at the eastern basin margin and at the Latakia Ridge, on top of anticlines where the salt thins. This observation suggests a direct relationship 
between reduced salt thickness and increased fluid escape in the Lebanese offshore, as has been demonstrated elsewhere in the Eastern Mediterranean (Bertoni et al., 2017). However, visible fluid escape is absent at the proximal pinch-out of the salt; i.e. where the salt thins and progressively disappears in the extensional area at the Eastern margin of the basin. This observation indicates that the presence of a subsalt trap structure is just as important as the reduced salt thickness to form fluid escape pipes. The anticlines in more distal positions within our dataset do not leak, despite potentially hosting fluids. We attribute this to a combination of smaller anticline size and thicker salt cover (1200-1500 m). The Oceanus structure (Cartwright et al., 2018) is an exception. Its large structure must have accommodated enough fluids to increase the overpressure above the high fracture threshold, thus overcoming the thick salt cover. However, we cannot exclude fluid leakage from anticlines in the deeper offshore outside our dataset, where additional overpressure generation mechanisms may be active.

The pipe cluster at the Latakia Ridge exemplifies the importance of thinned salt and anticline presence in facilitating across-salt leakage (Figs. 7 and 8). This thrust-related fold is a 4-way structural trap where the fluids migrating into it leak in absence of an efficient top seal. The anticline started deforming during the latest MSC (Hall et al., 2005), thus limiting evaporite deposition on top of the structure. Later growth of the structure may have caused salt to flow off the anticline crest, causing further salt thinning at its apex. The salt progressively thins towards the anticline culmination, becoming absent or sub-seismic resolution (c. 10-40 m) in the area where the pipes develop. Therefore, the area where the salt is absent strictly defines the fluid escape extent (Fig. 7).

\subsection{Highly sheared pipes}

Along the Lebanese margin, the root of the pipes appears shifted downwards along the anticlines flank; i.e. older pipes seem to emanate from the anticline flanks, not crest (Figs. 3, 6). Before now, a similar geometry has been hypothesized but never demonstrated at the Saida-Tyr fold B by Kirkham et al. (2019) (Fig. 12). Pipe emission from the flank of the anticlines is not reasonable as the fold culmination represents the point of highest buoyancy forces and likely fluid leakage, as demonstrated by the location of the most recent pipes across our dataset (e.g. Fig. 3a). Here, we hypothesize that the apparent displacement of the pipe roots down the anticline flank may result from very high shear strains due to the large drag force acting on the base-salt. Indeed, the pipes may have been sheared to such a degree (i.e. highly-sheared pipes) that the lower, gently dipping portion closer to the base-salt is no longer imaged in the seismic data 
despite its root still occurring at the anticline crest (Fig. 12). This observation is accurate for all the pipe trails in the northern Levant Basin, except for the Oceanus Structure, which shows all the pipe roots converge at a common leakage point (Cartwright et al., 2018). A high degree of shearing of the pipe base along the anticlines flank may record the fold amplification during the Plio-Pleistocene, intra-salt deformation, or a combination of both processes.

\subsection{Evolution of fluid escape recorded by pipe trails}

Fluid expulsion started asynchronously among the pipe trails during the Late Pliocene/Early Pleistocene and is continuing at present. The $1.8 \mathrm{Ma}$ reflection gives a spot age estimate for the trail formation, dividing them into two groups (i.e. pre- and post-1.8 Ma; Fig. 10c). The intra-RSB stratigraphic units offer a better, alternative calibration over the entire life span of each trail, allowing the relative age of the pipes to be correlated across the margin (Evans et al., 2020). The first pipe of each trail falls within RSB units of different ages (Fig. 10c), showing variability in the exact timing of initial fluid escape along the margin.

Prominent anticlines along the Lebanese offshore experienced an initial, geologically brief episode of overpressure buildup and fluid expulsion that is separated from the more recent fluid escape by a period of inactivity. We reconstructed the fluid escape activity by considering the pipes position in terms of relative time during which fluid expulsion was either active or quiescent. The oldest trail in each anticline started during T1 (excluding the significantly younger PTs 1 and 9, which started in T4 and T8, respectively). On this basis and for the purpose of this discussion, we approximate the start of fluid escape as being contemporaneous along the Lebanese margin. Fluid emission initiated with a brief episode that was followed by a longer quiescent period (Fig. 10C). This first episode of fluid escape most likely led to a significant reduction of fluid volume and pressure within the trap, as expected and commonly recognized in basins where fluid escape occurs (e.g. Deville and Guerlais, 2009; Rocco et al., 2017). The resultant lower pressure prevented new hydrofracturing across the entire margin during a relatively long interval, as testified by the long gap between the oldest pipe group and the younger features (Fig. 10). A second period of fluid release begun when sufficient overpressure built up again and represents the main fluid leakage phase in the northern Levant Basin. This phase started during T2 and is still active, mostly in the Saida-Tyr anticlines. The recorded fluid escape suggests that the Levant Basin tilt generated an exceptional initial pulse of overpressure along the entire Lebanese margin, which was able to overcome the salt seal. Because of the absence of further major tectonic changes, sufficient overpressure required time to be re- 
established by more local processes, such as hydrocarbon generation within individual sub-basins and permeability of local carrier beds.

Because pipe formation likely requires hydrofracturing by fluid-generated overpressure, the distribution of pipes along the trails can be used as a proxy for fluid input in the anticlines. The pipes formed during the second fluid escape period record cycles in hydrofracturing and quiescence, indicating overpressure oscillations due to alternating fluid charge and discharge (Fig. 10). These overpressure oscillations are not homogeneous between the various anticlines, as indicated by the different pipe distributions within trails. While the basin tilt is likely continuing to favor fluid migration from the deep basin, the diverse overpressure oscillations are most likely governed by local factors. Rate of hydrocarbon production, efficiency of migration from the source rocks, trap size and geometry, reservoir porosity and permeability, and salt characteristics are all possible factors. A similar variability of fluid influx into traps is widely documented in hydrocarbon reservoirs (e.g. Deville and Guerlais, 2009; Oppo et al., 2013) and in fluid escape systems (Judd and Hovland, 2007; Maestrelli et al., 2017; Oppo et al., 2013).

The variability of trap charge and discharge is particularly evident in the pipe trails originating from fold $B$ at Saida-Tyr (Fig. 4b). In this location various trails (i.e. PT2, 3, 4, 5) develop in an area where the salt and overburden translate uniformly away from the structure (i.e. uniform velocity along fold strike) (Evans et al., 2020), thus contemporaneous pipes fall within the same RSB interval (Fig. 10). The total length of the pipe trails varies by up to c. $4 \mathrm{~km}$ among these closely spaced trails. This variation does not have a defined trend; i.e. trails are neither progressively longer nor shorter moving north. The different lengths also indicate distinct start times for the initiation of the trails, thus pointing to an independent fluid escape history for each. This hypothesis is supported by the widely differing distributions of pipes within the four trails (Fig. 10). These differences are significant and may reflect hydraulically independent sectors within the anticline. Amplitude and variance attribute analyses show that the Saida fault inversion did not disrupt the lateral continuity of the NW-SE-striking normal faults within fold B (Fig. 13). Therefore, we infer that the leakage points along the anticline crest are located within different tilted fault blocks. It is reasonable to hypothesize that the normal faults act as barriers or baffle lateral fluid movement, thus creating trap sectors displaying different cycles of overpressure build up and release.

\section{Conclusions}


We analyzed novel 3D seismic data offshore Lebanon to reconstruct overpressure generation mechanisms and fluid escape duration and cyclicity following the deposition of the thick Messinian salt along the continental margin of northern Levant Basin. The high number of fluid escape pipes occurring in the northern Levant Basin proves the existence of a highly active regional petroleum system able to generate large volumes of hydrocarbons over a relatively long time span.

The Lebanese offshore experienced diffuse fluid expulsion since the Late Pliocene/Early Pleistocene, which peaked in the Late Pleistocene. The initial pipe formation is asynchronous across the basin despite concentrating within a narrow time interval coincident with the main uplift of the eastern sector of the basin. We interpret the uplift as the main event leading to cross-evaporite fluid escape in this region of the Eastern Mediterranean, because its role in transferring overpressured fluids into prominent anticlines along the basin margin. Dissimilarities in the initiation of fluid expulsion from a single anticline and, more generally, across the Levant Basin suggest that, after an initial fluid escape episode linked to the margin uplift, local dynamics of fluid migration and overpressure buildup over-imposed on the controls acting at a regional scale. In particular, it can be observed that: 1) the pipes location is strongly controlled by the structural arrangement of the sub-salt units; 2 ) the cyclicity of overpressure and fluid charge/discharge is regulated by fluid dynamics dependent on the individual structures.

In conclusion, recent efforts in the study of salt basins not yet extensively deformed by halokinesis continue contributing to unravel the processes driving overpressure generation and fluid escape through thick salt. While in the southern areas of the Eastern Mediterranean cross-evaporite fluid escape has been mainly attributed to the MSC and compaction disequilibrium, we argue that in the northern Levant Basin this is not suitable; here fluid escape was mainly driven by the tectonic evolution of the margin. In this frame, our study shows that the causes of cross-evaporite fluid escape can be multiple, vary over time, act in synergy, and have different impacts in the various areas of salt giant basins.

\section{Acknowledgements}

We gratefully acknowledge Ramadan Ghalayini, Wissam Chbat, and the Lebanese Petroleum Administration (LPA) for the provision of data without which this project would not have been possible; Schlumberger for granting Petrel@ academic licenses. We would like to thank Editor Craig Magee and Reviewers Chantelle Roelofse, Fadi Nader, and Aurélien Gay for their constructive comments, which contributed to improve this article. 


\section{Funding statement}

This research did not receive any specific grant from funding agencies in the public, commercial, or notfor-profit sectors.

\section{Data availability statement}

The data that support the findings of this study are available from LPA. Restrictions apply to the availability of these data, which were used under license for this study.

\section{Conflict of Interest}

No conflict of interest is declared.

\section{References}

Al-Balushi, A.N., Neumaier, M., Fraser, A.J., Jackson, C.A.-L., 2016. The impact of the Messinian salinity crisis on the petroleum system of the Eastern Mediterranean: a critical assessment using 2D petroleum system modelling. Pet. Geosci. 22, 357-379. https://doi.org/10.1144/petgeo2016054

Allen, H., Jackson, C.A.-L., Fraser, A.J., 2016. Gravity-driven deformation of a youthful saline giant: the interplay between gliding and spreading in the Messinian basins of the Eastern Mediterranean. Pet. Geosci. 22, 340-356. https://doi.org/10.1144/petgeo2016-034

Andresen, K.J., Huuse, M., Schødt, N.H., Clausen, L.F., Seidler, L., 2011. Hydrocarbon plumbing systems of salt minibasins offshore Angola revealed by three-dimensional seismic analysis. AAPG Bull. 95, 1039-1065. https://doi.org/10.1306/12131010046

Barabasch, J., Ducros, M., Hawie, N., Bou Daher, S., Nader, F.H., Littke, R., 2018. Integrated 3D forward stratigraphic and petroleum system modeling of the Levant Basin, Eastern Mediterranean. Basin Res. bre.12318. https://doi.org/10.1111/bre.12318

Barnes, A.E., 2016. Handbook of Poststack Seismic Attributes, Geophysical References Series. Society of Exploration Geophysicists. https://doi.org/10.1190/1.9781560803324

Berlepsch, T. von, Haverkamp, B., 2016. Salt as a Host Rock for the Geological Repository for Nuclear Waste. Elements 12, 257-262. https://doi.org/10.2113/gselements.12.4.257

Bertoni, C., Cartwright, J.A., 2005. 3D seismic analysis of circular evaporite dissolution structures, Eastern Mediterranean. J. Geol. Soc. 162, 909-926. https://doi.org/10.1144/0016-764904-126

Bertoni, C., Kirkham, C., Cartwright, J., Hodgson, N., Rodriguez, K., 2017. Seismic indicators of focused fluid flow and cross-evaporitic seepage in the Eastern Mediterranean. Mar. Pet. Geol. 88, 472488. https://doi.org/10.1016/j.marpetgeo.2017.08.022

Bou Daher, S., Ducros, M., Michel, P., Hawie, N., Nader, F.H., Littke, R., 2016. 3D thermal history and maturity modelling of the Levant Basin and its eastern margin, offshore-onshore Lebanon. Arab. J. Geosci. 9, 440. https://doi.org/10.1007/s12517-016-2455-1

Brown, A., 2011. Interpretation of Three-Dimensional Seismic Data, AAPG Memoir 42, 7th edition. ed. AAPG \& SEG.

Brown, A.R., 2001. Color in seismic display. Lead. Edge 20, 549-549. https://doi.org/10.1190/1.1438992 
Capozzi, Oppo, D., Taviani, M., 2017. Cold seepages: An economic tool for hydrocarbon appraisal. AAPG Bull. 101, 617-623. https://doi.org/10.1306/011817DIG17041

Cartwright, J., Kirkham, C., Bertoni, C., Hodgson, N., Rodriguez, K., 2018. Direct calibration of salt sheet kinematics during gravity-driven deformation. Geology 46, 623-626. https://doi.org/10.1130/G40219.1

Cartwright, J., Santamarina, C., 2015. Seismic characteristics of fluid escape pipes in sedimentary basins: Implications for pipe genesis. Mar. Pet. Geol. 65, 126-140. https://doi.org/10.1016/j.marpetgeo.2015.03.023

Cartwright, J., Stewart, S., Clark, J., 2001. Salt dissolution and salt-related deformation of the Forth Approaches Basin, UK North Sea. Mar. Pet. Geol. 18, 757-778. https://doi.org/10.1016/S02648172(01)00019-8

Cartwright, J.A., Jackson, M.P.A., 2008. Initiation of gravitational collapse of an evaporite basin margin: The Messinian saline giant, Levant Basin, eastern Mediterranean. Geol. Soc. Am. Bull. 120, 399413. https://doi.org/10.1130/B26081X.1

Chopra, S., Marfurt, K.J., 2007. Seismic Attributes for Prospect Identification and Reservoir Characterization, Geophysical Developments Series. Society of Exploration Geophysicists and European Association of Geoscientists and Engineers. https://doi.org/10.1190/1.9781560801900

Davison, I., 2009. Faulting and fluid flow through salt. J. Geol. Soc. 166, 205-216. https://doi.org/10.1144/0016-76492008-064

de Mahiques, M.M., Schattner, U., Lazar, M., Sumida, P.Y.G., Souza, L.A.P. de, 2017. An extensive pockmark field on the upper Atlantic margin of Southeast Brazil: spatial analysis and its relationship with salt diapirism. Heliyon 3, e00257. https://doi.org/10.1016/j.heliyon.2017.e00257

Deville, E., Guerlais, S.-H., 2009. Cyclic activity of mud volcanoes: Evidences from Trinidad (SE Caribbean). Mar. Pet. Geol. 26, 1681-1691. https://doi.org/10.1016/j.marpetgeo.2009.03.002

Dimitrov, L., Woodside, J., 2003. Deep sea pockmark environments in the eastern Mediterranean. Mar. Geol., Sedimentary Processes and Seafloor Hydrocarbon Emission on Deep European Continental Margins 195, 263-276. https://doi.org/10.1016/S0025-3227(02)00692-8

Eruteya, O.E., Waldmann, N., Schalev, D., Makovsky, Y., Ben-Avraham, Z., 2015. Intra- to post-Messinian deep-water gas piping in the Levant Basin, SE Mediterranean. Mar. Pet. Geol. 66, 246-261. https://doi.org/10.1016/j.marpetgeo.2015.03.007

Esestime, P., Hewitt, A., Hodgson, N., 2016. Zohr - A newborn carbonate play in the Levantine Basin, East-Mediterranean. First Break 34, 8.

Evans, S., Jackson, C.A.-L., Oppo, D., 2020. Taking the pulse of salt-detached gravity gliding in the eastern Mediterranean. EarthArXiv. https://doi.org/10.31223/osf.io/5usv7

Evans, S.L., Jackson, C.A. -L., 2019. Base-salt relief controls salt-related deformation in the Outer Kwanza Basin, offshore Angola. Basin Res. bre.12390. https://doi.org/10.1111/bre.12390

Feng, Y.E., Yankelzon, A., Steinberg, J., Reshef, M., 2016. Lithology and characteristics of the Messinian evaporite sequence of the deep Levant Basin, eastern Mediterranean. Mar. Geol. 376, 118-131. https://doi.org/10.1016/j.margeo.2016.04.004

Foschi, M., Cartwright, J.A., Peel, F.J., 2014. Vertical anomaly clusters: Evidence for vertical gas migration across multilayered sealing sequences. AAPG Bull. 98, 1859-1884. https://doi.org/10.1306/04051413121

Fu, B., Aharon, P., 1998. Sources of Hydrocarbon-Rich Fluids Advecting on the Seafloor in the Northern Gulf of Mexico. Gulf Coast Assoc. Geol. Soc. Trans. 48, 73-81.

Gardosh, M.A., Tannenbaum, E., 2014. The Petroleum Systems of Israel. Mem. 106 Pet. Syst. Tethyan Reg. 179-216. 
Gay, A., Lopez, M., Berndt, C., Séranne, M., 2007. Geological controls on focused fluid flow associated with seafloor seeps in the Lower Congo Basin. Mar. Geol. 244, 68-92.

https://doi.org/10.1016/j.margeo.2007.06.003

Ghalayini, R., Daniel, J.-M., Homberg, C., Nader, F.H., Comstock, J.E., 2014. Impact of Cenozoic strike-slip tectonics on the evolution of the northern Levant Basin (offshore Lebanon): Cenozoic tectonics of the Levant basin. Tectonics 33, 2121-2142. https://doi.org/10.1002/2014TC003574

Ghalayini, R., Nader, F.H., Bou Daher, S., Hawie, N., Chbat, W.E., 2018. PETROLEUM SYSTEMS OF LEBANON: AN UPDATE AND REVIEW. J. Pet. Geol. 41, 189-214. https://doi.org/10.1111/jpg.12700

Gradmann, S., Hübscher, C., Ben-Avraham, Z., Gajewski, D., Netzeband, G., 2005. Salt tectonics off northern Israel. Mar. Pet. Geol. 22, 597-611. https://doi.org/10.1016/j.marpetgeo.2005.02.001

Gvirtzman, Z., Reshef, M., Buch-Leviatan, O., Ben-Avraham, Z., 2013. Intense salt deformation in the Levant Basin in the middle of the Messinian Salinity Crisis. Earth Planet. Sci. Lett. 379, 108-119. https://doi.org/10.1016/j.epsl.2013.07.018

Hall, J., Calon, T.J., Aksu, A.E., Meade, S.R., 2005. Structural evolution of the Latakia Ridge and Cyprus Basin at the front of the Cyprus Arc, Eastern Mediterranean Sea. Mar. Geol. 221, 261-297. https://doi.org/10.1016/j.margeo.2005.03.007

Hansen, J.P.V., Cartwright, J.A., Huuse, M., Clausen, O.R., 2005. 3D seismic expression of fluid migration and mud remobilization on the Gjallar Ridge, offshore mid-Norway. Basin Res. 17, 123-139. https://doi.org/10.1111/j.1365-2117.2005.00257.x

Haq, B., Gorini, C., Baur, J., Moneron, J., Rubino, J.-L., 2020. Deep Mediterranean's Messinian evaporite giant: How much salt? Glob. Planet. Change 184, 103052. https://doi.org/10.1016/j.gloplacha.2019.103052

Hawie, N., Gorini, C., Deschamps, R., Nader, F.H., Montadert, L., Granjeon, D., Baudin, F., 2013. Tectonostratigraphic evolution of the northern Levant Basin (offshore Lebanon). Mar. Pet. Geol. 48, 392-410. https://doi.org/10.1016/j.marpetgeo.2013.08.004

Hübscher, C., Tahchi, E., Klaucke, I., Maillard, A., Sahling, H., 2009. Salt tectonics and mud volcanism in the Latakia and Cyprus Basins, eastern Mediterranean. Tectonophysics 470, 173-182. https://doi.org/10.1016/j.tecto.2008.08.019

Jackson, M.P.A., Hudec, M.R., 2017. Influence of Salt on Petroleum Systems, in: Salt Tectonics: Principles and Practice. Cambridge University Press, Cambridge, pp. 424-456. https://doi.org/10.1017/9781139003988.020

Jackson, M.P.A., Hudec, M.R., 2005. Stratigraphic record of translation down ramps in a passive-margin salt detachment. J. Struct. Geol. 27, 889-911. https://doi.org/10.1016/j.jsg.2005.01.010

Judd, Hovland, M., 2007. Seabed Fluid Flow: The Impact on Geology, Biology and the Marine Environment. Cambridge University Press, Cambridge. https://doi.org/10.1017/СВ09780511535918

Kabir, M., Iacopini, D., Hartley, A., Maselli, V., Oppo, D., 2019. Seismic Characterization of the Top Messinian Unit in North Eastern Levant Basin, Offshore Lebanon. Presented at the 34th IAS Meeting of Sedimentology, IAS, Rome, Italy.

Kallweit, R.S., Wood, L.C., 1982. The limits of resolution of zero-phase wavelets. GEOPHYSICS 47, 10351046. https://doi.org/10.1190/1.1441367

Kirkham, C., Cartwright, J., Bertoni, C., Rodriguez, K., Hodgson, N., 2019. 3D kinematics of a thick salt layer during gravity-driven deformation. Mar. Pet. Geol. 110, 434-449. https://doi.org/10.1016/j.marpetgeo.2019.07.036

Kirkham, C., Cartwright, J., Hermanrud, C., Jebsen, C., 2018. The genesis of mud volcano conduits through thick evaporite sequences. Basin Res. 30, 217-236. https://doi.org/10.1111/bre.12250 
Kirkham, C., Cartwright, J., Hermanrud, C., Jebsen, C., 2017. The spatial, temporal and volumetric analysis of a large mud volcano province within the Eastern Mediterranean. Mar. Pet. Geol. 81, 1-16. https://doi.org/10.1016/j.marpetgeo.2016.12.026

Lebedeva-Ivanova, N., Polteau, S., Bellwald, B., Planke, S., Berndt, C., Henriksen Stokke, H., 2018. Toward one-meter resolution in 3D seismic. Lead. Edge 37, 794-864. https://doi.org/10.1190/tle37110818.1

Leduc, A.M., Davies, R.J., Swarbrick, R.E., Imber, J., 2013. Fluid flow pipes triggered by lateral pressure transfer in the deepwater western Niger Delta. Mar. Pet. Geol. 43, 423-433. https://doi.org/10.1016/j.marpetgeo.2012.12.005

Lofi, J., Déverchère, J., Gaullier, V., Gillet, H., Gorini, C., Guennoc, P., Loncke, L., Maillard, A., Sage, F., Thinon, I., 2011. Seismic Atlas of the Messinian Salinity Crisis markers in the Mediterranean and Black Seas, Mémoire de la Société Géologique n.s. Société Géologique de France.

Loncke, L., Mascle, J., Fanil Scientific Parties, 2004. Mud volcanoes, gas chimneys, pockmarks and mounds in the Nile deep-sea fan (Eastern Mediterranean): geophysical evidences. Mar. Pet. Geol. 21, 669-689. https://doi.org/10.1016/j.marpetgeo.2004.02.004

Madof, A.S., Bertoni, C., Lofi, J., 2019. Discovery of vast fluvial deposits provides evidence for drawdown during the late Miocene Messinian salinity crisis. Geology 47, 171-174. https://doi.org/10.1130/G45873.1

Maestrelli, D., lacopini, D., Jihad, A.A., Bond, C.E., Bonini, M., 2017. Seismic and structural characterization of fluid escape pipes using 3D and partial stack seismic from the Loyal Field (Scotland, UK): A multiphase and repeated intrusive mechanism. Mar. Pet. Geol. 88, 489-510. https://doi.org/10.1016/j.marpetgeo.2017.08.016

Marlow, L., Kornpihl, K., Kendall, C., 2011. 2-D Basin modeling study of petroleum systems in the Levantine Basin, Eastern Mediterranean. GeoArabia 16, 17-42.

Matmon, A., Enzel, Y., Zilberman, E., Heimann, A., 1999. Late Pliocene and Pleistocene reversal of drainage systems in northern Israel: tectonic implications. Geomorphology 28, 43-59. https://doi.org/10.1016/S0169-555X(98)00097-X

McManus, K.M., Hanor, J.S., 1993. Diagenetic evidence for massive evaporite dissolution, fluid flow, and mass transfer in the Louisiana Gulf Coast. Geology 21, 727-730. https://doi.org/10.1130/00917613(1993)021<0727:DEFMED>2.3.CO;2

Meilijson, A., Hilgen, F., Sepúlveda, J., Steinberg, J., Fairbank, V., Flecker, R., Waldmann, N.D., Spaulding, S.A., Bialik, O.M., Boudinot, F.G., Illner, P., Makovsky, Y., 2019. Chronology with a pinch of salt: Integrated stratigraphy of Messinian evaporites in the deep Eastern Mediterranean reveals longlasting halite deposition during Atlantic connectivity. Earth-Sci. Rev. 194, 374-398. https://doi.org/10.1016/j.earscirev.2019.05.011

Morley, C.K., Warren, J., Tingay, M., Boonyasaknanon, P., Julapour, A., 2014. Comparison of modern fluid distribution, pressure and flow in sediments associated with anticlines growing in deepwater (Brunei) and continental environments (Iran). Mar. Pet. Geol. 51, 210-229. https://doi.org/10.1016/j.marpetgeo.2013.11.011

Moss, J.L., Cartwright, J., 2010. 3D seismic expression of $\mathrm{km}$-scale fluid escape pipes from offshore Namibia: 3D seismic expression of km-scale fluid escape pipes. Basin Res. 22, 481-501. https://doi.org/10.1111/j.1365-2117.2010.00461.x

Nader, F.H., Inati, L., Ghalayini, R., Hawie, N., Bou Daher, S., 2018. Key geological characteristics of the Saida-Tyr Platform along the eastern margin of the Levant Basin, offshore Lebanon: implications for hydrocarbon exploration. Oil Gas Sci. Technol. - Rev. D'IFP Energ. Nouv. 73, 50. https://doi.org/10.2516/ogst/2018045

Netzeband, G.L., Hübscher, C.P., Gajewski, D., 2006. The structural evolution of the Messinian evaporites in the Levantine Basin. Mar. Geol. 230, 249-273. https://doi.org/10.1016/j.margeo.2006.05.004 
Oppo, D., Capozzi, R., Picotti, V., 2013. A new model of the petroleum system in the Northern Apennines, Italy. Mar. Pet. Geol. 48, 57-76. https://doi.org/10.1016/j.marpetgeo.2013.06.005

Oppo, D., Hovland, M., 2019. Role of deep-sourced fluids on the initiation and growth of isolated carbonate build-ups. Mar. Pet. Geol. 105, 141-157. https://doi.org/10.1016/j.marpetgeo.2019.04.019

Pichel, L.M., Peel, F., Jackson, C.A.-L., Huuse, M., 2018. Geometry and kinematics of salt-detached ramp syncline basins. J. Struct. Geol. 115, 208-230. https://doi.org/10.1016/j.jsg.2018.07.016

Reijenstein, H.M., Posamentier, H.W., Bhattacharya, J.P., 2011. Seismic geomorphology and highresolution seismic stratigraphy of inner-shelf fluvial, estuarine, deltaic, and marine sequences, Gulf of ThailandSeismic Geomorphology and Stratigraphy in the Gulf of Thailand. AAPG Bull. 95, 1959-1990. https://doi.org/10.1306/03151110134

Robertson, A.H.F., Dixon, J.E., Brown, S., Collins, A., Morris, A., Pickett, E., Sharp, I., Ustaömer, T., 1996. Alternative tectonic models for the Late Palaeozoic-Early Tertiary development of Tethys in the Eastern Mediterranean region. Geol. Soc. Lond. Spec. Publ. 105, 239-263. https://doi.org/10.1144/GSL.SP.1996.105.01.22

Rocco, S., Woods, A.W., Harrington, J., Norris, S., 2017. An experimental model of episodic gas release through fracture of fluid confined within a pressurized elastic reservoir. Geophys. Res. Lett. 44, 751-759. https://doi.org/10.1002/2016GL071546

Roveri, M., Lugli, S., Manzi, V., Gennari, R., Schreiber, B.C., 2014. High-resolution strontium isotope stratigraphy of the Messinian deep Mediterranean basins: Implications for marginal to central basins correlation. Mar. Geol. 349, 113-125. https://doi.org/10.1016/j.margeo.2014.01.002

Salazar, J.A., Knapp, J.H., Knapp, C.C., Pyles, D.R., 2014. Salt tectonics and Pliocene stratigraphic framework at MC-118, Gulf of Mexico: An integrated approach with application to deep-water confined structures in salt basins. Mar. Pet. Geol. 50, 51-67. https://doi.org/10.1016/j.marpetgeo.2013.11.003

Schoenherr, J., Urai, J.L., Kukla, P.A., Littke, R., Schleder, Z., Larroque, J.-M., Newall, M.J., Al-Abry, N., AlSiyabi, H.A., Rawahi, Z., 2007. Limits to the sealing capacity of rock salt: A case study of the infraCambrian Ara Salt from the South Oman salt basin. AAPG Bull. 91, 1541-1557. https://doi.org/10.1306/06200706122

Selley, R., Sonnenberg, S., 2015. Elements of Petroleum Geology. Elsevier. https://doi.org/10.1016/C2010-0-67090-8

Steinberg, J., Gvirtzman, Z., Folkman, Y., Garfunkel, Z., 2011. Origin and nature of the rapid late Tertiary filling of the Levant Basin. Geology 39, 355-358. https://doi.org/10.1130/G31615.1

Tingay, M.R.P., Hillis, R.R., Swarbrick, R.E., Morley, C.K., Damit, A.R., 2007. 'Vertically transferred' overpressures in Brunei: Evidence for a new mechanism for the formation of high-magnitude overpressure. Geology 35, 1023-1026. https://doi.org/10.1130/G23906A.1

Wagner, B.H., Jackson, M.P.A., 2011. Viscous flow during salt welding. Tectonophysics 510, 309-326. https://doi.org/10.1016/j.tecto.2011.07.012

Warren, 2017. Salt usually seals, but sometimes leaks: Implications for mine and cavern stabilities in the short and long term. Earth-Sci. Rev. 165, 302-341. https://doi.org/10.1016/j.earscirev.2016.11.008

Warren, 2016. Evaporites: A Geological Compendium, 2nd ed. Springer International Publishing. https://doi.org/10.1007/978-3-319-13512-0

Warren, 2006. Evaporites: Sediments, Resources and Hydrocarbons. Springer Science \& Business Media.

Widess, M., 1973. How thin is a thin bed? Geophysics 38, 1021-1240. https://doi.org/10.1190/1.1440403

Yardley, G.S., Swarbrick, R.E., 2000. Lateral transfer: a source of additional overpressure? Mar. Pet. Geol. 17, 523-537. https://doi.org/10.1016/S0264-8172(00)00007-6 
Yilmaz, Ö., 2001. Seismic Data Analysis, Investigations in Geophysics. Society of Exploration Geophysicists. https://doi.org/10.1190/1.9781560801580

Zhang, R., Castagna, J., 2011. Seismic sparse-layer reflectivity inversion using basis pursuit decompositionSeismic reflection inversion. Geophysics 76, R147-R158. https://doi.org/10.1190/geo2011-0103.1

Zitter, T.A.C., Huguen, C., Woodside, J.M., 2005. Geology of mud volcanoes in the eastern Mediterranean from combined sidescan sonar and submersible surveys. Deep Sea Res. Part Oceanogr. Res. Pap. 52, 457-475. https://doi.org/10.1016/j.dsr.2004.10.005 


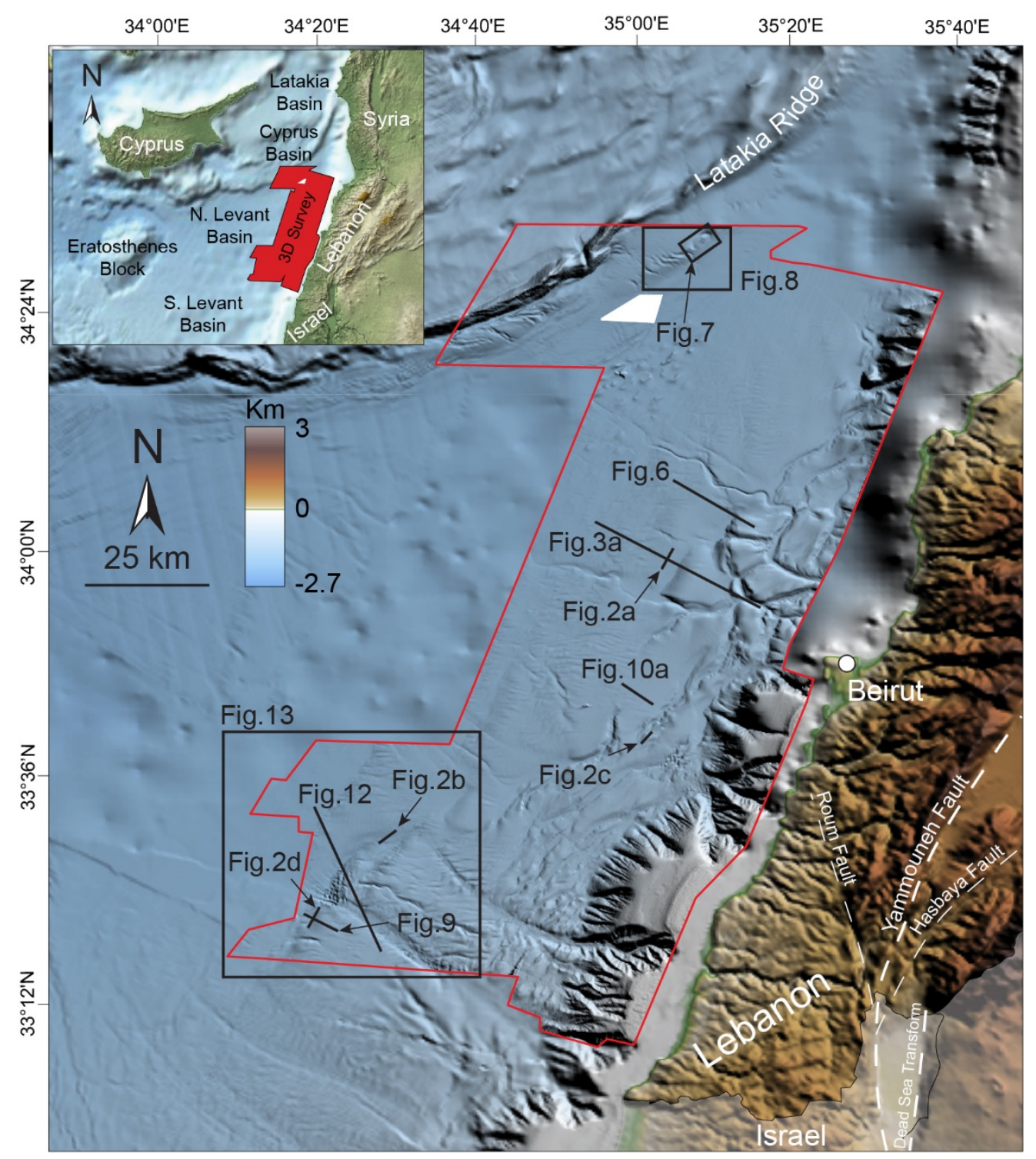

Fig. 1 Map of the northern Levant Basin showing the areal coverage of the interpreted 3D seismic data (red polygon) and the location of figures referenced in text. Bathymetry is derived from the 3D seismic data, GEBCO, and EDMOnet databases. 


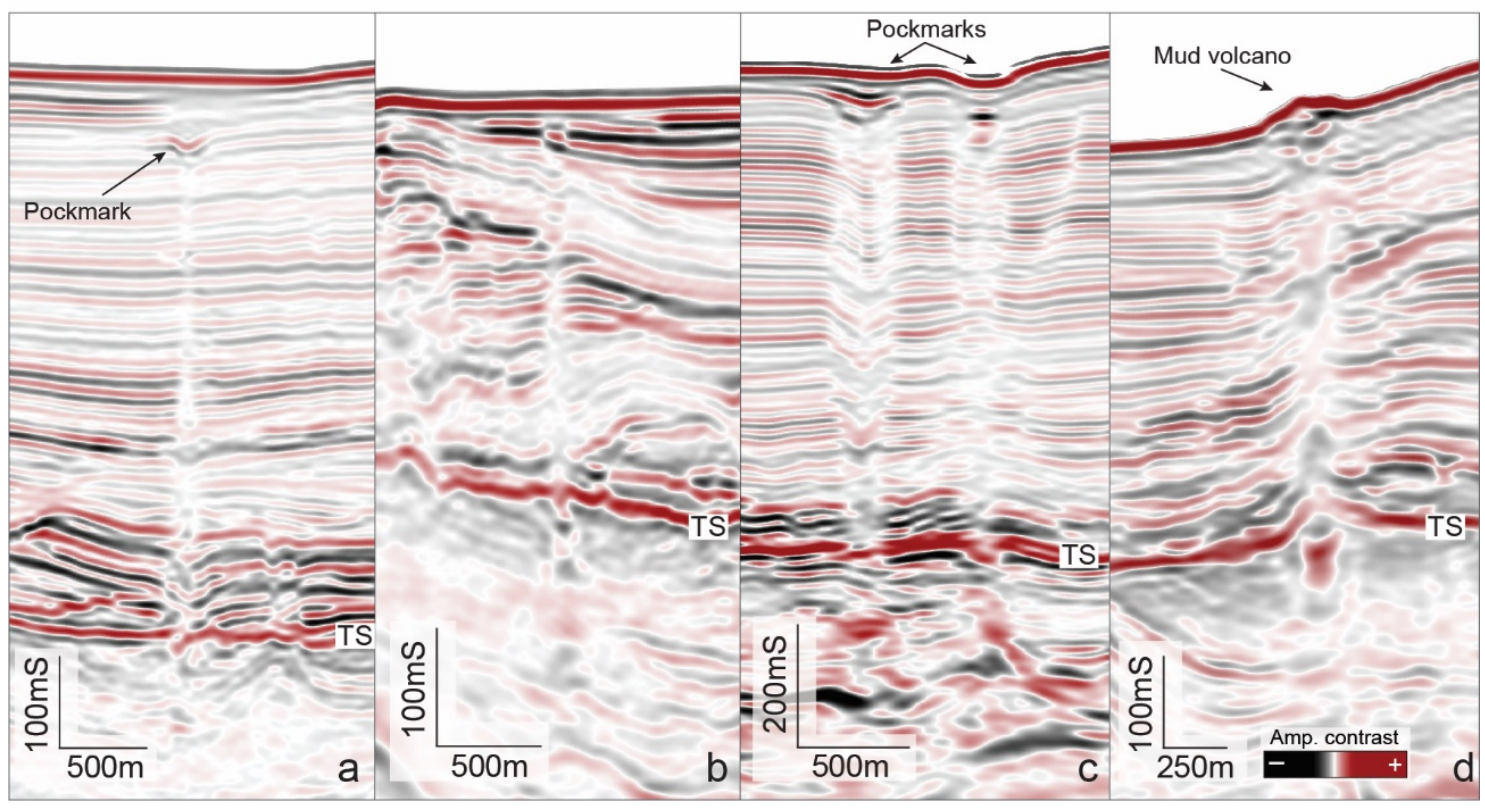

Fig. 2 Seismic expression of different fluid escape pipe geometries. a) upward tapering conical pipe showing a clear pockmark terminus marked by an amplitude anomaly; b) cylindrical pipe roughly maintaining the same diameter; c) downward tapering conical pipes with large pockmark at the seafloor and in the shallow subsurface; d) mud volcano feeder conduit showing lateral migration of fluid into the hosting sediments. 


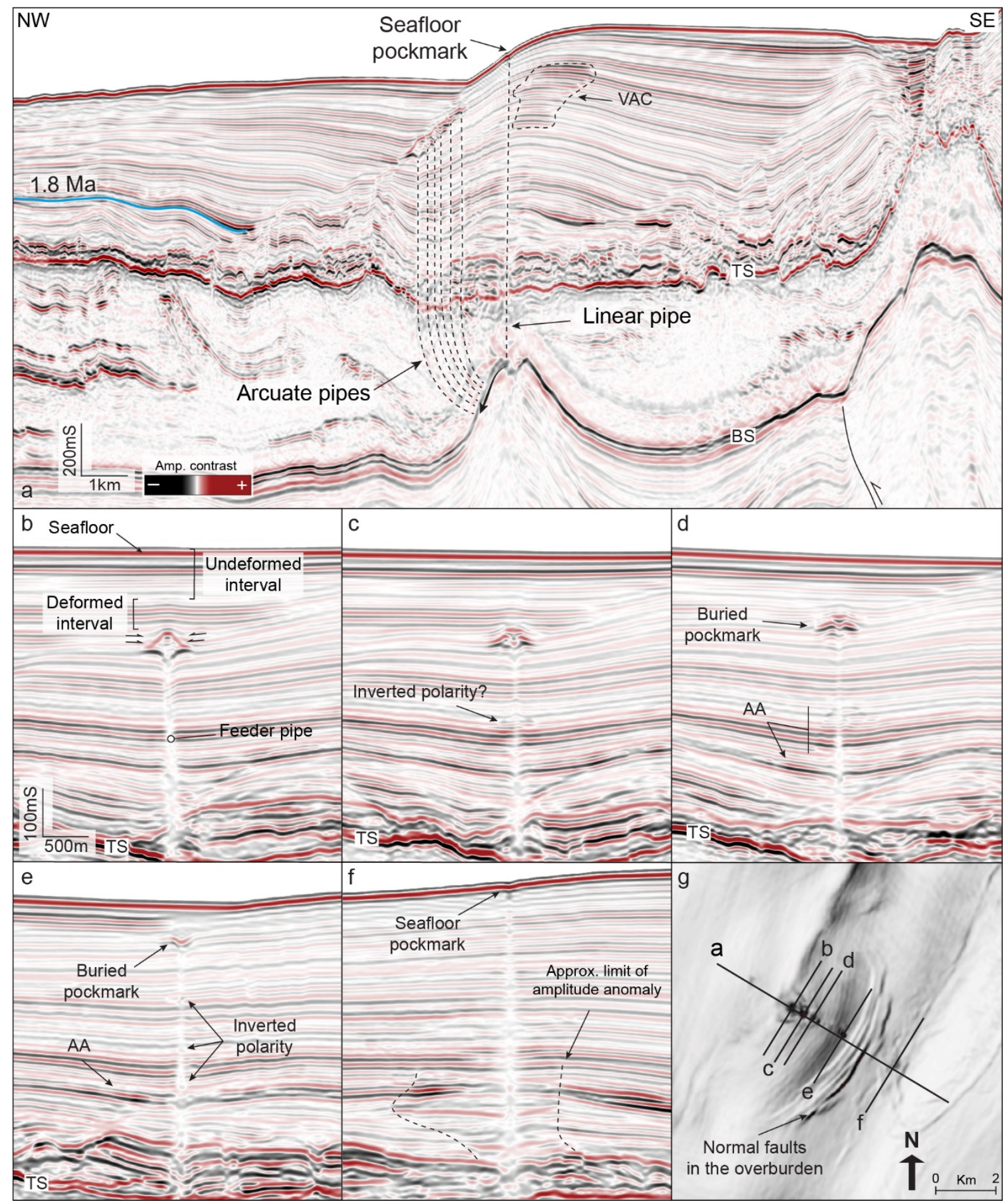

Fig. 3 a) Seismic cross-section showing pipe trail 9 (see Section 4.2), which develops in between two superimposed RSBs. The 1.8 Ma marker horizon (from Kirkham et al., 2019) is indicated. b-f) crosssections perpendicular to the trail direction (see ' $\mathrm{g}$ ' for location) showing the progressive transformation of the pipes terminus from mud volcano to pockmark. g) variance time slice at $-2372 \mathrm{~ms}$. A small set of 
normal accommodation faults does not crosscut the salt unit but links with amplitude anomalies within the overburden. TS: top-salt, BS: base-salt, AAs: amplitude anomalies, VAC: vertical anomaly cluster. See Fig. S1 in supplemental material for uninterpreted seismic section. 

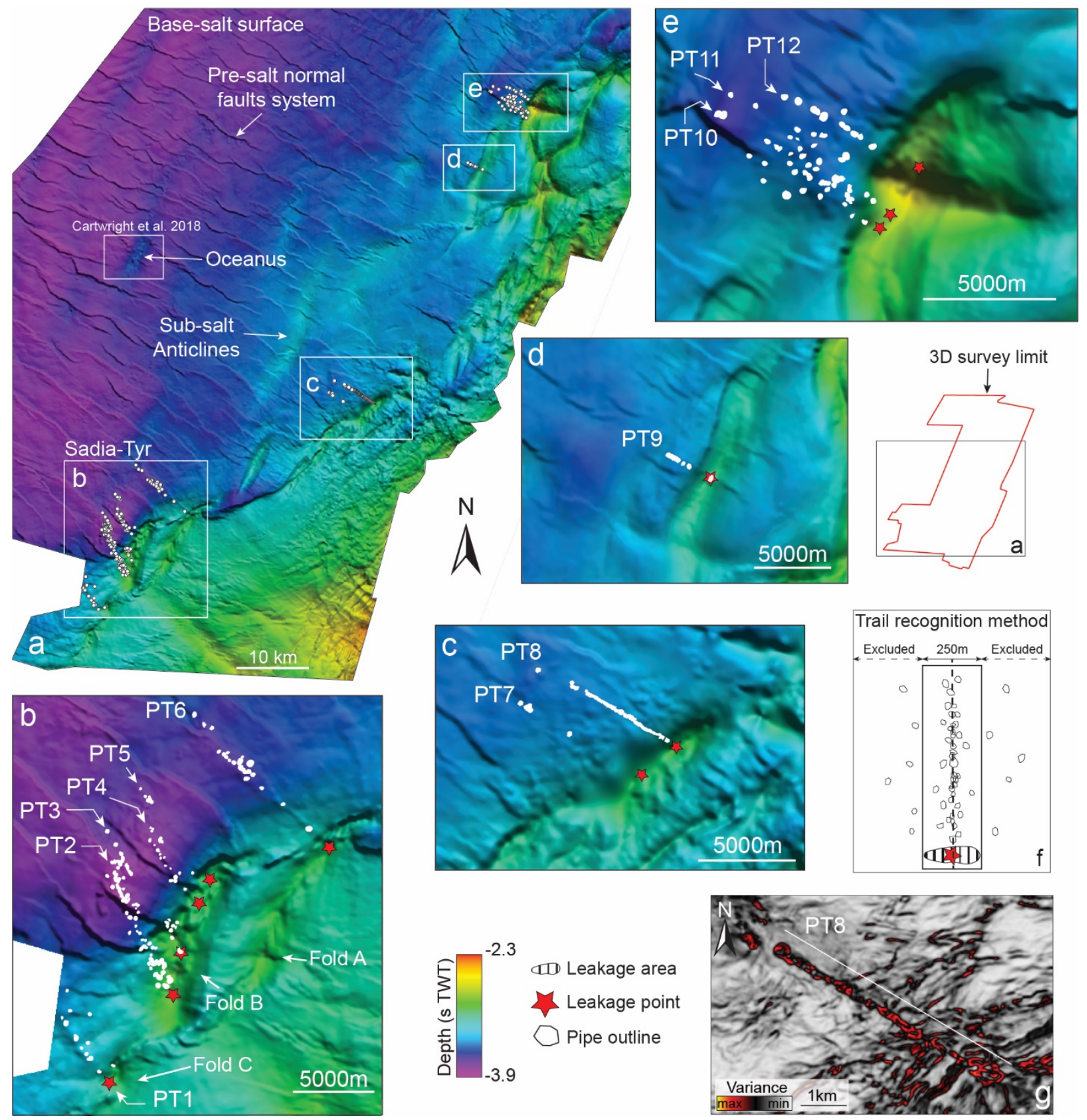

Fig. 4 Base-salt surface showing the location of pipes and pipe trails along the margin. a) extended overview of the dataset showing sub-salt anticlines and normal fault system, and the location of Oceanus pipe trail. $b$-e) details of the twelve pipe trails occurring along the northern Levant margin. $f$ ) Schematic representation of the pipe trails identification methodology. g) Horizontal slice of the variance attribute cube showing the pipes within PT8 as circular to sub-circular discontinuities in the seismic signal. 


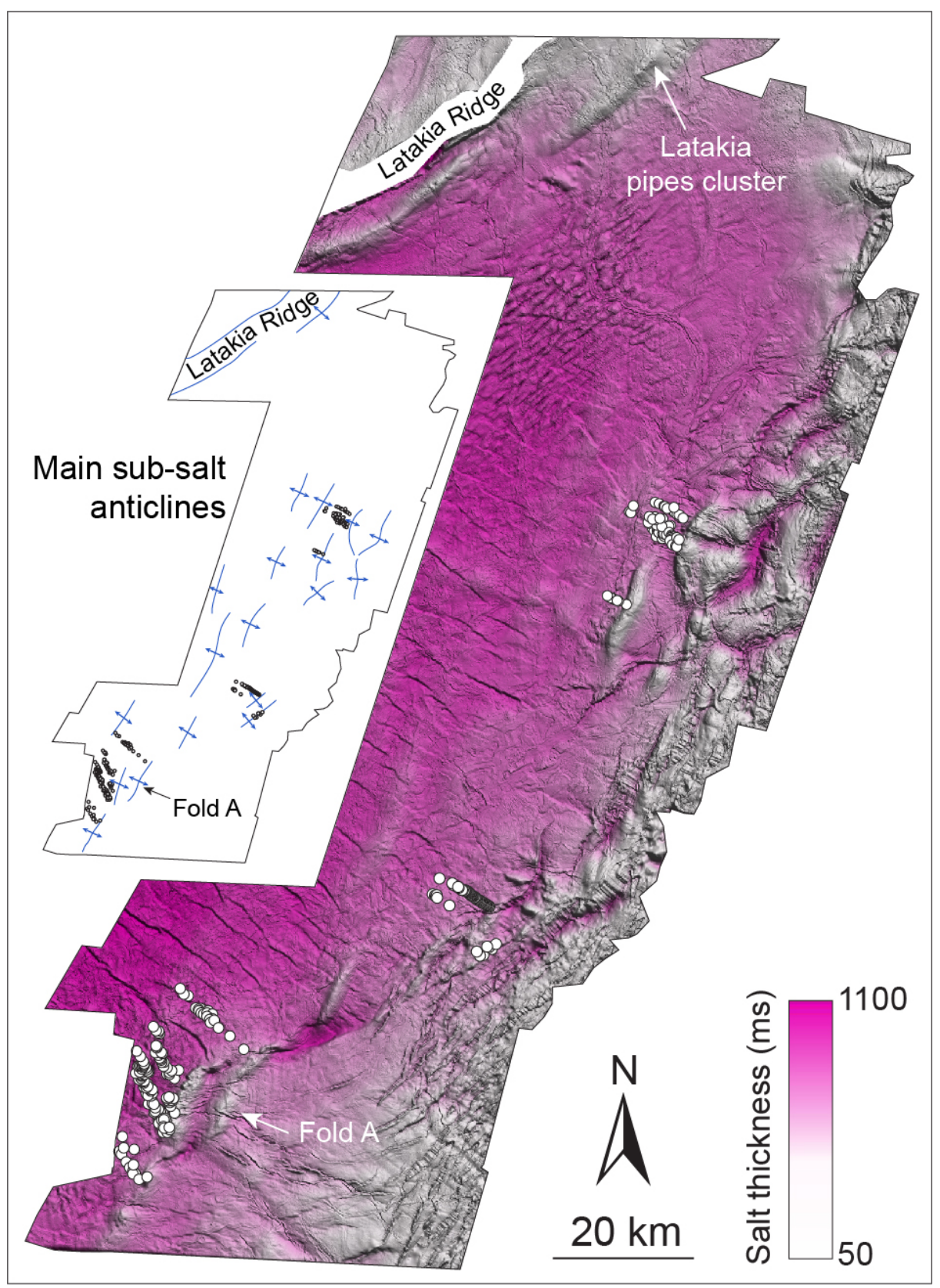

Fig. 5 Isopach map of the Messinian salt. The pipe trails constantly originate from the top of anticlines where the salt thickness is reduced. 

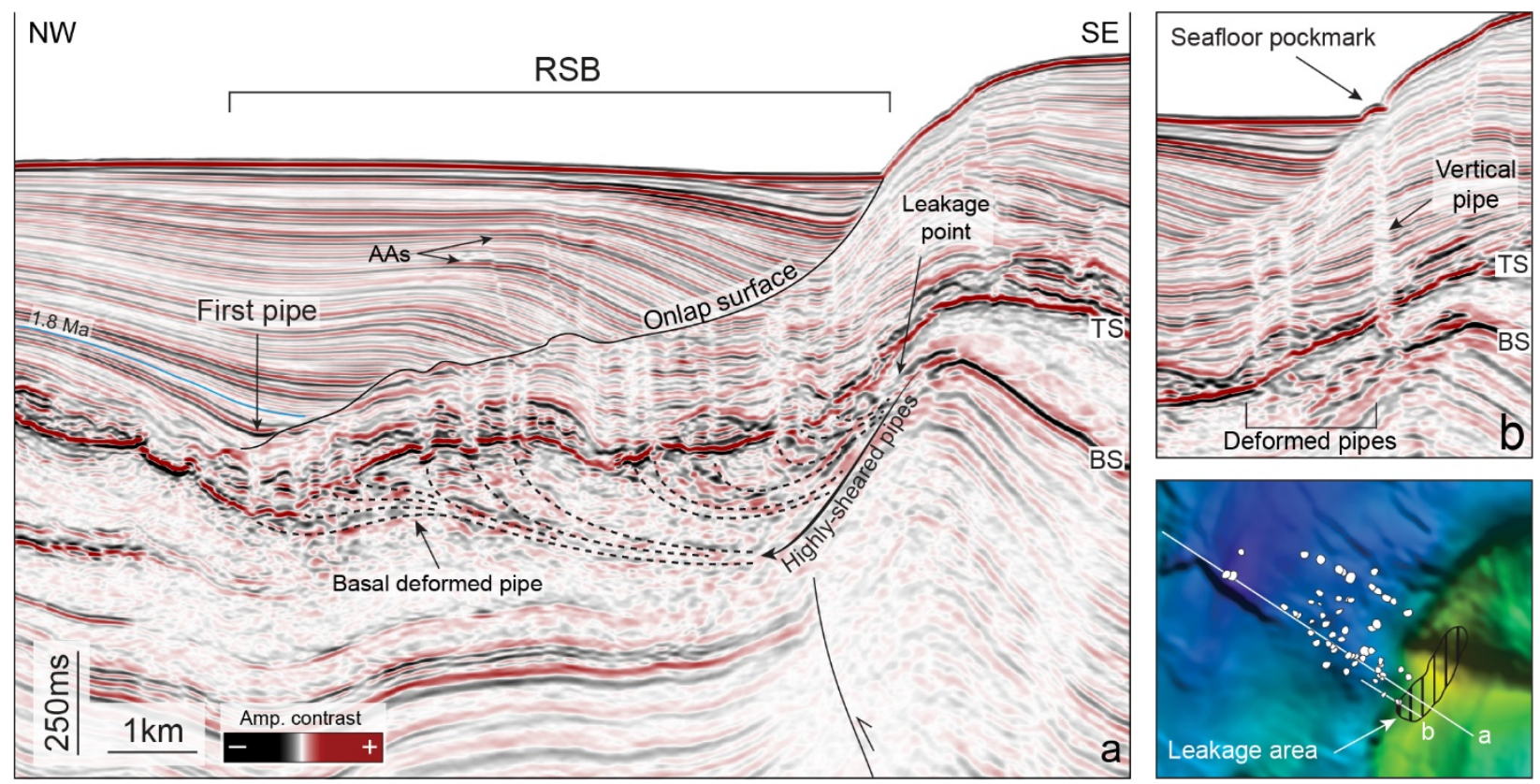

Fig. 6 a) seismic cross-section showing pipes originating from one thrust top anticline and progressively translated basinward. The dashed basal deformed pipe marks the present-day expression of the first fluid escape pipe within the salt. Other representative pipes are marked by dashed lines. Arrow indicates the apparent translation of the pipes root down the anticline flank from the leakage point, forming a highly sheared pipe (see also Section 5.3). b) Example of vertical pipe and pockmark on the present-day seafloor not yet deformed and translated by the salt movement. TS: top-salt, BS: basesalt, AAs: amplitude anomalies, RSB: ramp syncline basin. See Fig. S2 in supplemental material for uninterpreted seismic section. 


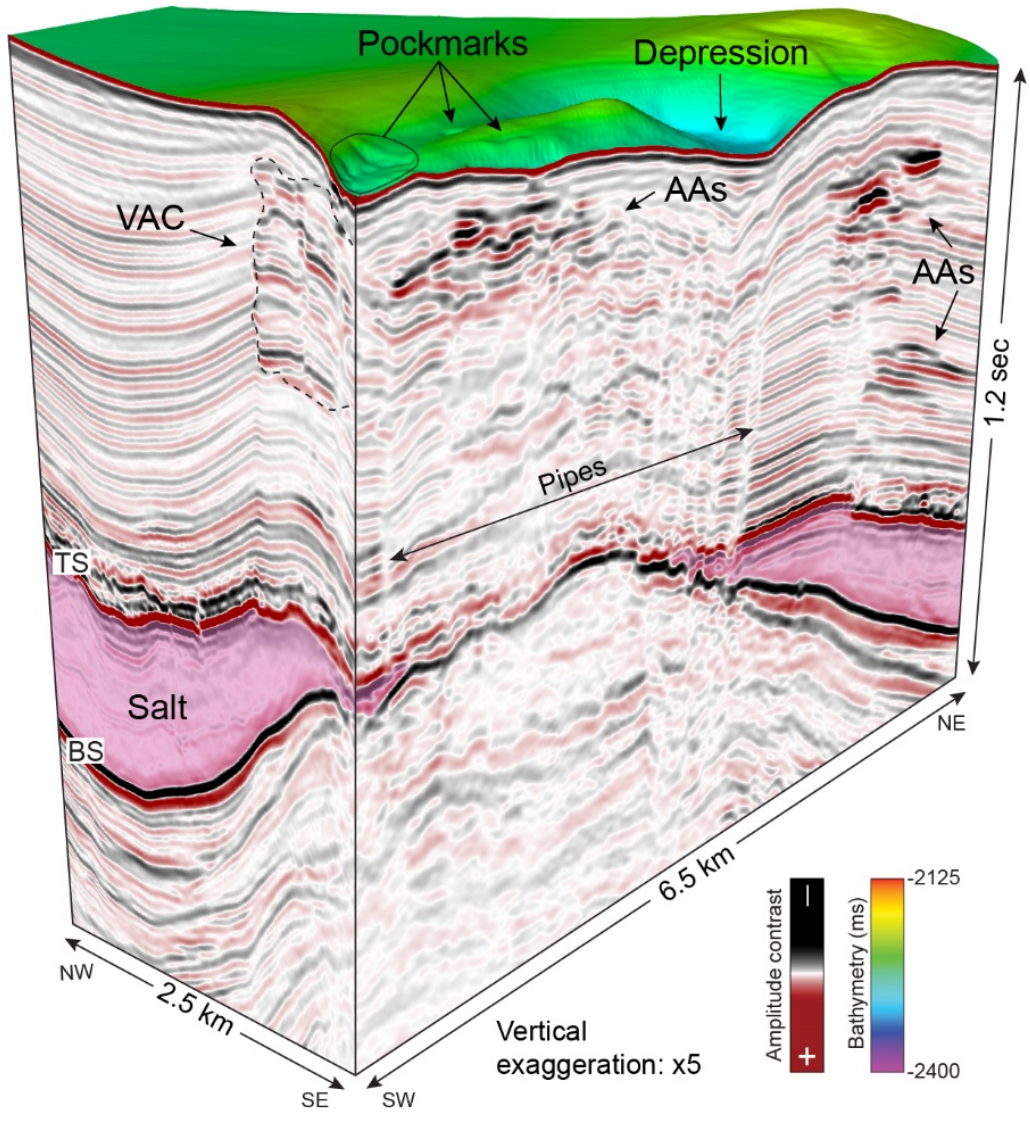

Fig.7 Perspective view of pipe cluster originating from a Latakia thrust anticline. Pockmarks occur on the seafloor within a depressed area directly overlying the pipes. The pipes are located only at the anticline culmination where salt is absent. The fluids migrate laterally in the salt overburden forming VACs. TS: top-salt, BS: base-salt, AAs: amplitude anomalies, VAC: vertical anomaly cluster. 


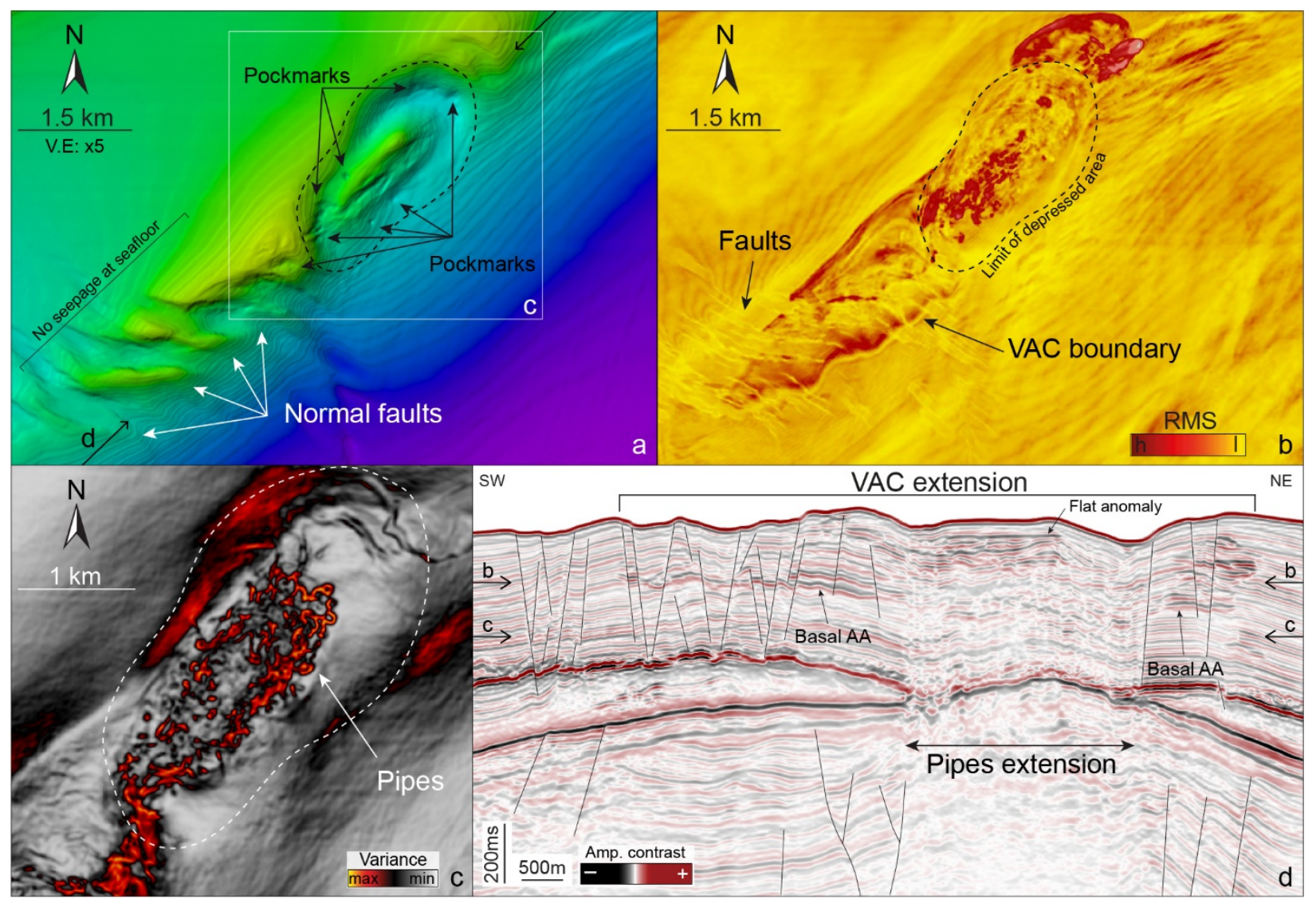

Fig. 8 a) seafloor bathymetry at the Latakia pipe cluster. The pockmarks are confined in the depressed zone (dashed area), while the graben area on the SW is barren of fluid emission features. Arrows indicate the location of seismic line of panel $d$. b) RMS calculated on time slice (see arrows in panel $d$ for location). The RMS clearly images the lateral extent of the VAC above the anticline. c) variance attribute calculated on a time slice (see arrows in panel $d$ for location) and showing the pipes cluster. d) Seismic cross-section through the pipes cluster showing the two systems of normal faults and the lateral extent of the VAC characterizing this structure. AAs: amplitude anomalies, VAC: vertical anomaly cluster. 


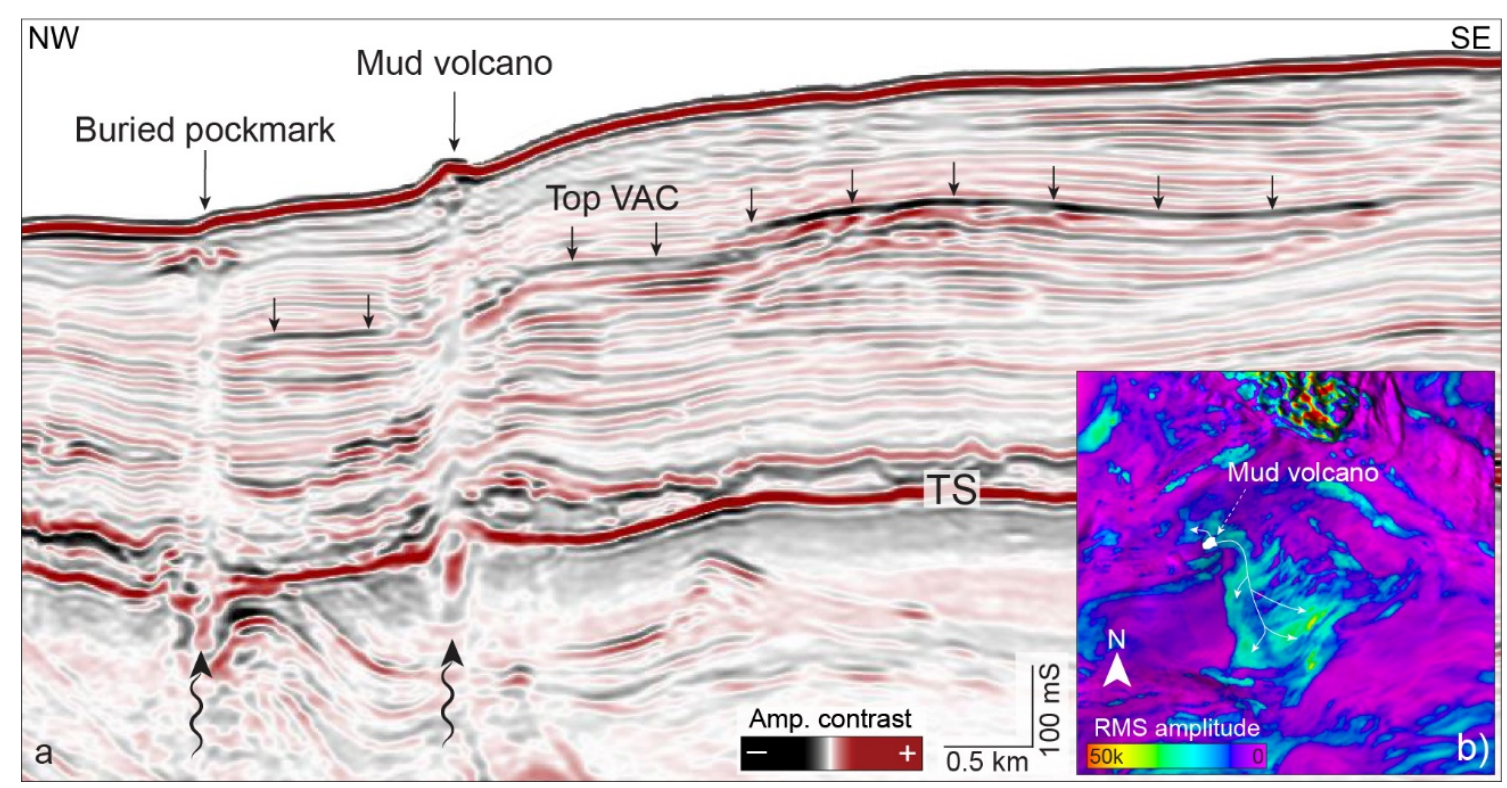

Fig. 9 a) vertical anomaly cluster originating from a mud volcano feeder pipe, which promotes the lateral up-dip fluid diffusion in the hosting sediment. b) RMS calculated on the VAC top to show the lateral extent of the amplitude anomaly and its origin from the mud volcano. 
Pipe Trail 8
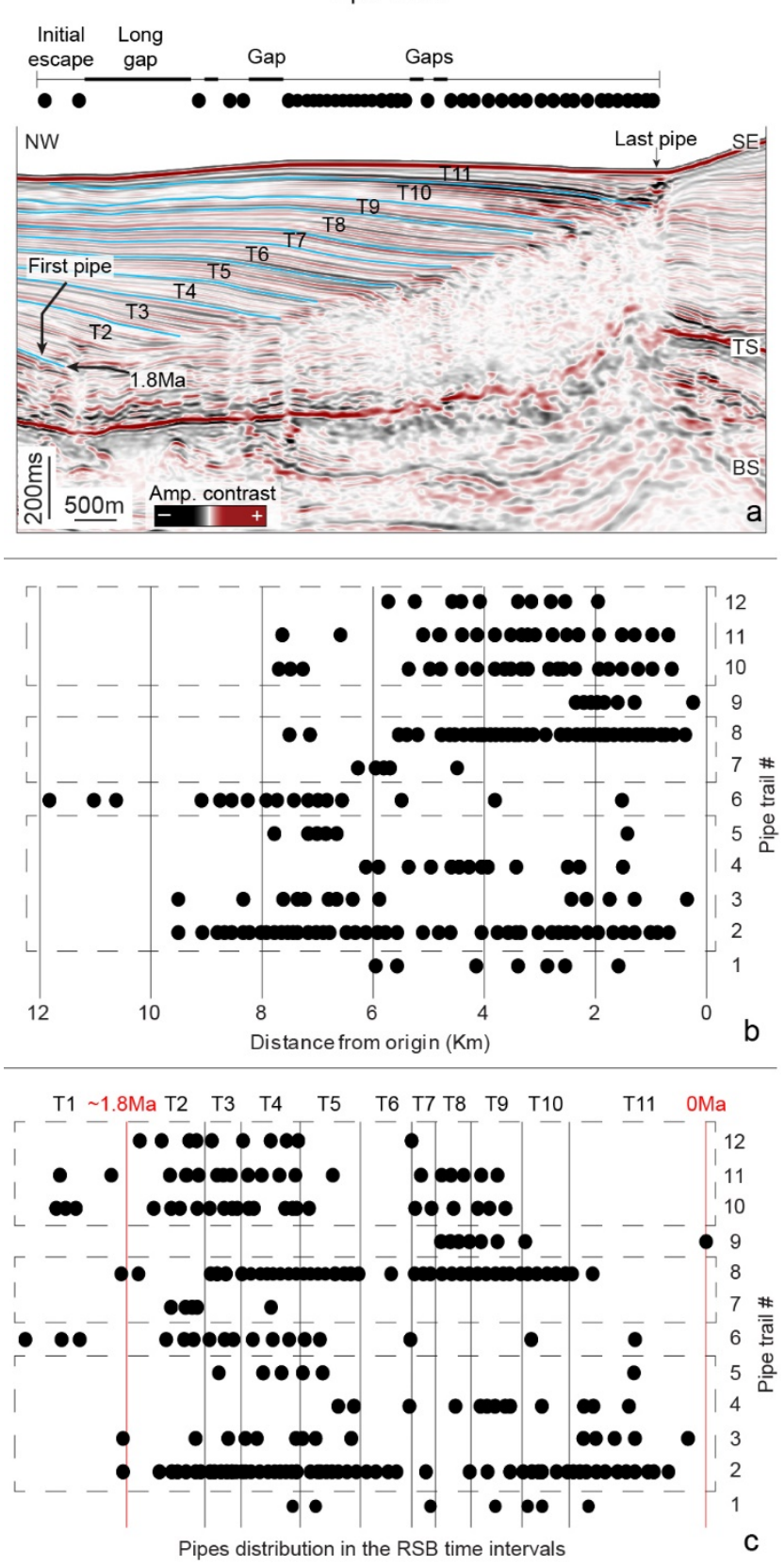

Fig. 10 Quantitative characterization of the pipe trails. a) example of trail (PT8) showing the relationship between the pipes distribution and the RSB time intervals. b) horizontal distance of each pipe in a trail (black dots) from their emission point at the anticlines crest. The dashed boxes group the trails originating from the same sub-salt anticline. c) distribution of the pipes within trails according to their occurrence into the time intervals (T1-T11) calculated though RSB analysis. In this figure, the length of the time intervals is displayed according to that of the anticline where PT2-5 occur. 


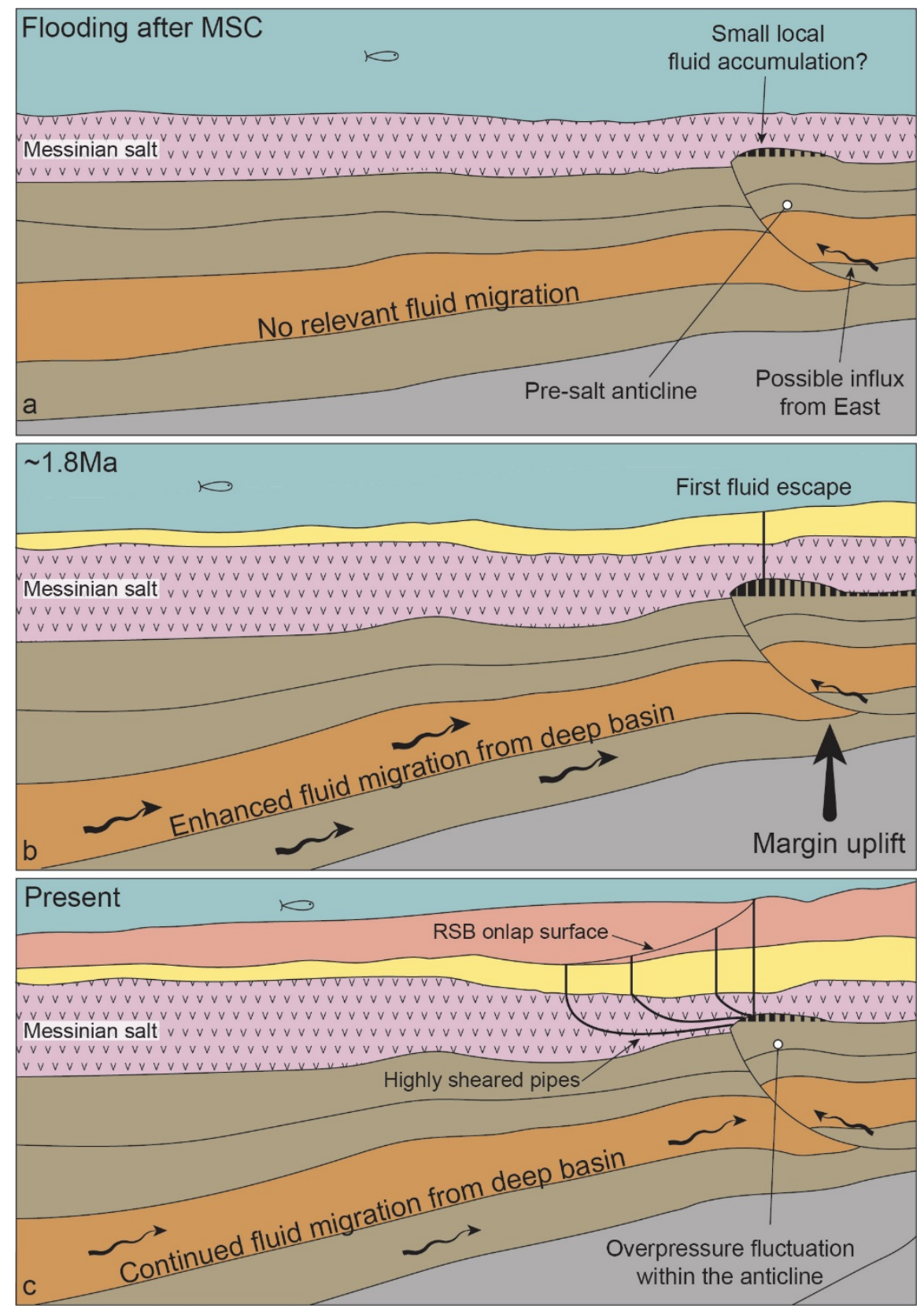

Fig. 11 Sketch of pipe trails evolution. An increased uplift of the Levant margin at c. 1.8Ma triggered enhanced fluid migration towards the sub-salt anticlines from the deeper areas of the basin (b). As a consequence, supra-lithostatic overpressure formed inside the anticlines leading to hydrofracture and the formation of the first pipes. During the subsequent period and until present, local processes govern overpressure buildup and the formation of cross-evaporite fluid escape. 


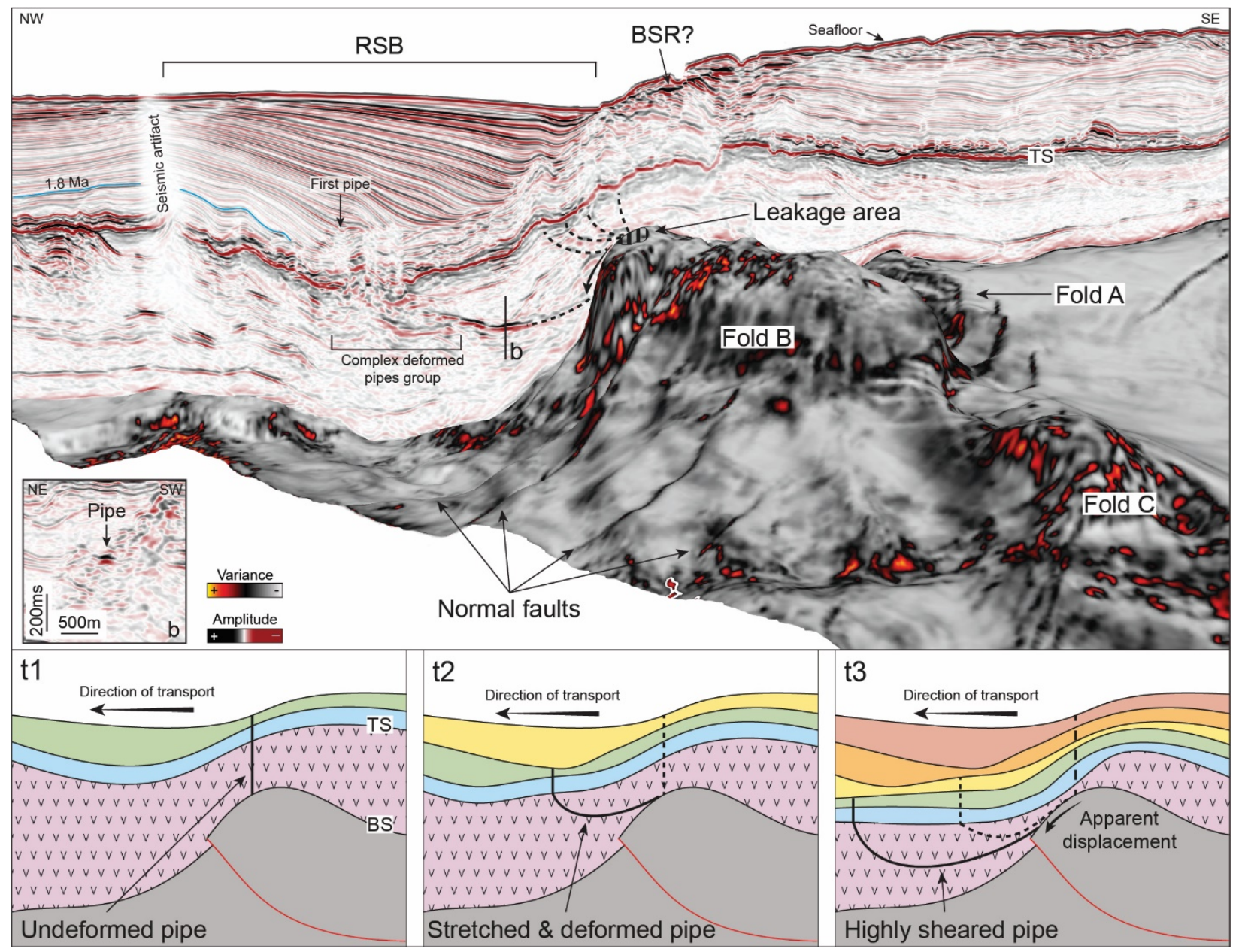

Fig. 12 Perspective view of pipe trail 3, originating from the culmination of fold B at Saida-Tyr. The variance attribute is calculated on the base-salt surface. Inset $b$ shows the cross-section of a deformed pipe within the salt as a narrow soft-kick anomaly. Bottom panels: sketch of pipes formation and deformation. t1) an initial pipe is formed vertically from the anticline culmination. At the same time the RSB starts forming following the basinward salt gliding; t2) the first pipe is translated basinward while its portion within the salt is progressively stretched and deformed in an arcuate geometry. A second pipe is formed; $\mathrm{t} 3$ ) as the gliding of salt and overburden proceeds, the first pipe is stretched to such an extent that it becomes 'super-sheared'. In this phase, its lowermost portion is too fragmented to be still visible in the seismic data and the root appears shifted along the anticline flank. The second pipe started to deform while a new one forms. TS: top-salt, RSB: ramp syncline basin, BSR: bottom-simulating reflector. 


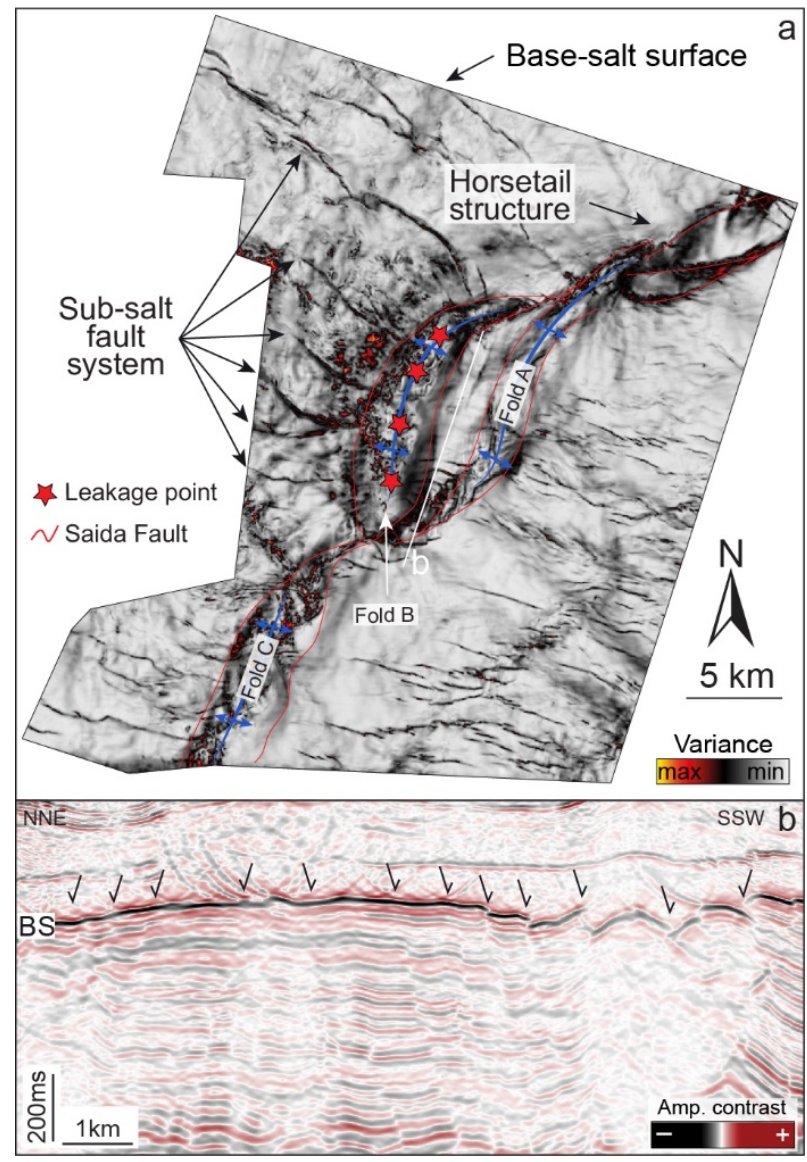

Fig. 13 a) variance attribute calculated on the base-salt surface to evidence the Saida-Tyr structure and show the interaction of the sub-salt fault system with the fold B (see also panel b). The location of fluid leakage points supports the hypothesis that the faults are barriers to fluid movement and form a compartmentalized trap, of which parts experienced fairly independent fluid charge and discharge histories. 